\title{
The chemistry of $\mathrm{OH}$ and $\mathrm{HO}_{2}$ radicals in the boundary layer over the tropical Atlantic Ocean
}

\author{
L. K. Whalley ${ }^{1,5}$, K. L. Furneaux ${ }^{1, \dagger}$, A. Goddard ${ }^{1}$, J. D. Lee ${ }^{2,6}$, A. Mahajan ${ }^{1}$, H. Oetjen ${ }^{1}$, K. A. Read ${ }^{2,6}$, N. Kaaden ${ }^{3}$, \\ L. J. Carpenter ${ }^{2}$, A. C. Lewis ${ }^{2,6}$, J. M. C. Plane ${ }^{1}$, E. S. Saltzman ${ }^{4}$, A. Wiedensohler ${ }^{3}$, and D. E. Heard ${ }^{1,5}$ \\ ${ }^{1}$ School of Chemistry, University of Leeds, Woodhouse Lane, Leeds, LS2 9JT, UK \\ ${ }^{2}$ Chemistry Department, University of York, Heslington, YO10 5DD, UK \\ ${ }^{3}$ Physics Department, Leibniz Institute for Tropospheric Research, Leipzig, Germany \\ ${ }^{4}$ Department of Earth System Science, University of California, Irvine, CA, USA \\ ${ }^{5}$ National Centre for Atmospheric Sciences, University of Leeds, Leeds, LS2 9JT, UK \\ ${ }^{6}$ National Centre for Atmospheric Sciences, University of York, Heslington, YO10 5DD, UK \\ ${ }^{\dagger}$ Sadly passed away 28 July 2009
}

Received: 9 July 2009 - Published in Atmos. Chem. Phys. Discuss.: 28 July 2009

Revised: 5 January 2010 - Accepted: 19 January 2010 - Published: 15 February 2010

\begin{abstract}
Fluorescence Assay by Gas Expansion (FAGE) has been used to detect ambient levels of $\mathrm{OH}$ and $\mathrm{HO}_{2}$ radicals at the Cape Verde Atmospheric Observatory, located in the tropical Atlantic marine boundary layer, during May and June 2007. Midday radical concentrations were high, with maximum concentrations of $9 \times 10^{6}$ molecule $\mathrm{cm}^{-3}$ and $6 \times 10^{8}$ molecule $\mathrm{cm}^{-3}$ observed for $\mathrm{OH}$ and $\mathrm{HO}_{2}$, respectively. A box model incorporating the detailed Master Chemical Mechanism, extended to include halogen chemistry, heterogeneous loss processes and constrained by all available measurements including halogen and nitrogen oxides, has been used to assess the chemical and physical parameters controlling the radical chemistry. The model was able to reproduce the daytime radical concentrations to within the $1 \sigma$ measurement uncertainty of $20 \%$ during the latter half of the measurement period but significantly under-predicted $\left[\mathrm{HO}_{2}\right]$ by $39 \%$ during the first half of the project. Sensitivity analyses demonstrate that elevated $[\mathrm{HCHO}](\sim 2 \mathrm{ppbv})$ on specific days during the early part of the project, which were much greater than the mean [HCHO] (328 pptv) used to constrain the model, could account for a large portion of the discrepancy between modelled and measured $\left[\mathrm{HO}_{2}\right]$ at this time. $\mathrm{IO}$ and $\mathrm{BrO}$, although present only at a few pptv, constituted $\sim 19 \%$ of the instantaneous sinks for $\mathrm{HO}_{2}$, whilst aerosol uptake and surface deposition to the ocean accounted
\end{abstract}

for a further $23 \%$ of the $\mathrm{HO}_{2}$ loss at noon. Photolysis of $\mathrm{HOI}$ and $\mathrm{HOBr}$ accounted for $\sim 13 \%$ of the instantaneous $\mathrm{OH}$ formation. Taking into account that halogen oxides increase the oxidation of $\mathrm{NO}_{\mathrm{x}}\left(\mathrm{NO} \rightarrow \mathrm{NO}_{2}\right)$, and in turn reduce the rate of formation of $\mathrm{OH}$ from the reaction of $\mathrm{HO}_{2}$ with $\mathrm{NO}, \mathrm{OH}$ concentrations were estimated to be $9 \%$ higher overall due to the presence of halogens. The increase in modelled $\mathrm{OH}$ from halogen chemistry gives an estimated $9 \%$ shorter lifetime for methane in this region, and the inclusion of halogen chemistry is necessary to model the observed daily cycle of $\mathrm{O}_{3}$ destruction that is observed at the surface. Due to surface losses, we hypothesise that $\mathrm{HO}_{2}$ concentrations increase with height and therefore contribute a larger fraction of the $\mathrm{O}_{3}$ destruction than at the surface.

\section{Introduction}

The $\mathrm{OH}$ radical is one of the most dominant oxidants in the troposphere. It is most prevalent in tropical regions where high levels of humidity and solar irradiance lead to high rates of $\mathrm{OH}$ production:

$$
\begin{aligned}
& \mathrm{O}_{3}+h v(\lambda<340 \mathrm{~nm}) \rightarrow \mathrm{O}_{2}+\mathrm{O}\left({ }^{1} \mathrm{D}\right) \\
& \mathrm{O}\left({ }^{1} \mathrm{D}\right)+\mathrm{H}_{2} \mathrm{O} \rightarrow 2 \mathrm{OH}
\end{aligned}
$$

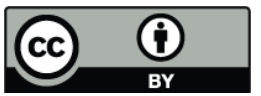

Correspondence to: $\mathrm{L}$. K. Whalley

(1.k.whalley@leeds.ac.uk)

Published by Copernicus Publications on behalf of the European Geosciences Union. 


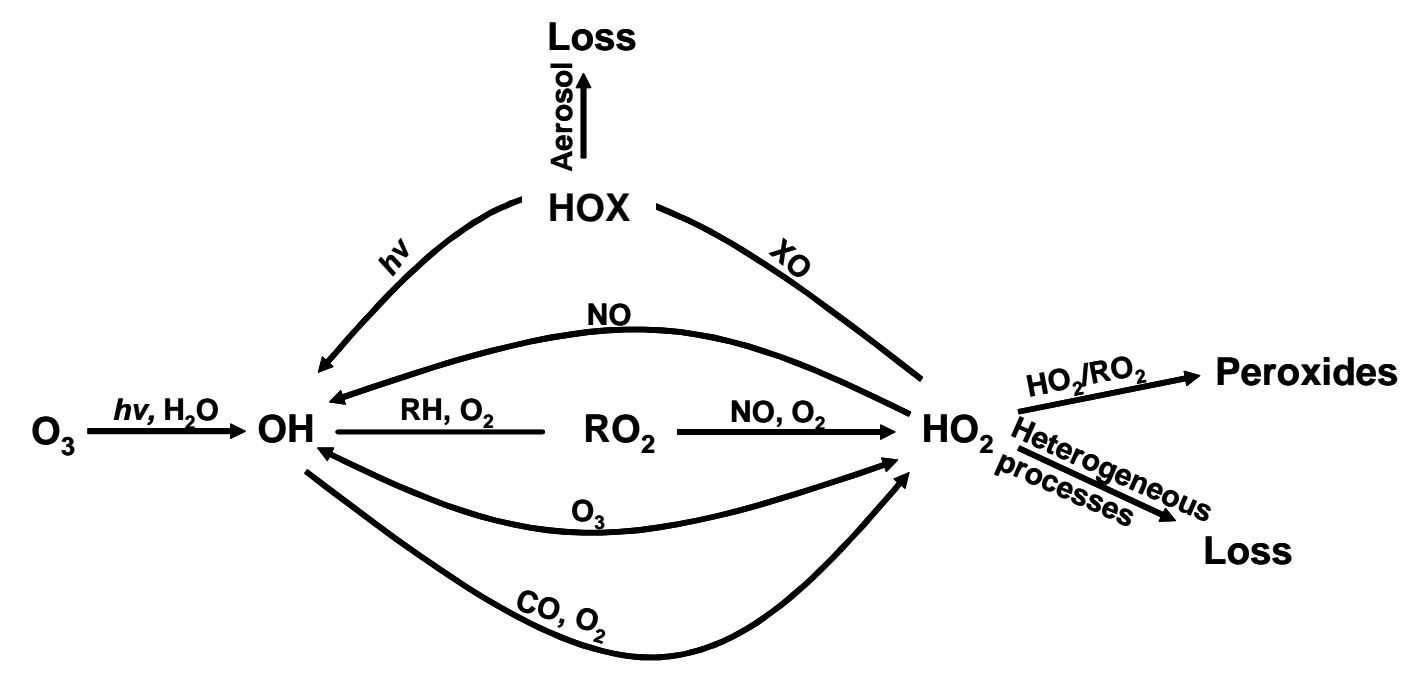

Fig. 1. Chemical reaction scheme showing the reactions affecting $\mathrm{OH}$ and $\mathrm{HO}_{2}$ concentrations in the remote $\mathrm{MBL}$. $\mathrm{X}=\mathrm{I}, \mathrm{Br}$ and $\mathrm{R}=$ alkyl group.

Around $80 \%$ of methane, the third most abundant greenhouse gas, is processed within the tropical troposphere by the $\mathrm{OH}$ radical with the tropical marine lower troposphere contributing $\sim 25 \%$ to the total tropospheric methane removal rate (Bloss et al., 2005a). The loss of methane is disproportionately high in the lower tropical troposphere compared to at higher altitudes in the tropical troposphere owing to the large temperature dependence of the reaction between methane and $\mathrm{OH}$; the reaction rate is $\sim 24$ times greater at the surface than at the tropopause in the tropics.

Despite the importance of the lower marine tropical troposphere, $\mathrm{OH}$ measurements in this region, and also those of $\mathrm{HO}_{2}$, which is closely coupled to $\mathrm{OH}$ through the reaction cycles shown in Fig. 1, are sparse. Aircraft measurements of $\mathrm{OH}$ and $\mathrm{HO}_{2}$ were made during the Pacific Exploratory Missions (PEM) (Hoell et al., 1996, 1997, 1999; Raper et al., 2001), with OH midday concentrations between $6-8 \times 10^{6}$ molecule $\mathrm{cm}^{-3}$ recorded in the tropical marine boundary layer (MBL) using the Selected Ion Chemical Ionisation Mass Spectrometer (SICIMS) technique (Mauldin III et al., 1999, 2001). Modelling studies (using a photochemical box model and a photostationary state point model) indicated that Reaction (R2) was the major source of $\mathrm{HO}_{\mathrm{x}}$ $\left(\mathrm{OH}+\mathrm{HO}_{2}\right)$ (contributing $\left.81 \%\right)$, while the major sinks involved the formation and subsequent loss of the peroxides of $\mathrm{H}_{2} \mathrm{O}_{2}$ and $\mathrm{CH}_{3} \mathrm{OOH}$ (Chen et al., 2001). The models under-predicted the measured MBL OH by $15-20 \%$; no halogen chemistry was included in these models. The primary focus of many of the PEM campaigns was the freetropopshere, and so measurements in the boundary layer were limited. $\mathrm{OH}$ measurements using Differential Optical Absorption Spectroscopy (DOAS) have been made onboard the R/V Polarstern, as part of the Air Chemistry and Lidar Studies of Tropospheric and Stratospheric Species on the Atlantic Ocean (ALBATROSS) project held in October/November 1996 (Brauers et al., 2001). OH data were collected over the latitudinal range $5^{\circ} \mathrm{N}$ to $40^{\circ} \mathrm{S}$ in the Atlantic. $\mathrm{OH}$ displayed a distinct diurnal profile with a maximum around local noon of $\sim 7 \times 10^{6}$ molecule $\mathrm{cm}^{-3}$. A simple photochemical box model, containing just $\mathrm{CO}$ and methane as sinks for $\mathrm{OH}$, on average underpredicted $\mathrm{OH}$ by $16 \%$, but was within the combined calibration errors associated with the $\mathrm{OH}, \mathrm{CO}$ and photolysis frequency measurements.

In background marine airmasses, which are low in volatile organic compounds (VOCs) and $\mathrm{NO}_{\mathrm{x}}$, with $\mathrm{HO}_{\mathrm{x}}$ generated mainly by Reactions (R1)-(R2) and removed primarily by the formation and subsequent loss of peroxides, modelled and measured $\mathrm{OH}$ concentrations are in reasonable agreement. In contrast to $\mathrm{OH}$, however, models often significantly overpredict $\mathrm{HO}_{2}$ in such airmasses when only this basic chemistry is considered (Sommariva et al., 2004, 2006; Kanaya et al., 2007).

The Southern Ocean Photochemistry Experiment (SOAPEX-2) was held at Cape Grim, in North Western Tasmania, Australia, in 1999 under extremely clean conditions $([\mathrm{NO}]<3$ pptv). Two chemical schemes were constructed to describe the free-radical budget; one containing just the oxidation of $\mathrm{CO}$ and methane, the other also describing the oxidation of non-methane hydrocarbons (NMHC) that were also measured (Sommariva et al., 2004). Box model calculations of $[\mathrm{OH}]$ using these two mechanisms agreed to within $5-10 \%$, implying a minor role for NMHC as an $\mathrm{OH}$ sink, and both over-predicted $[\mathrm{OH}]$ by $10-20 \%$. $\left[\mathrm{HO}_{2}\right]$, however, was overestimated by up to $40 \%$, but model agreement was improved by assuming an $\mathrm{HO}_{2}$ uptake coefficient to aerosol of unity (Sommariva et al., 2004). This, however, is probably an unreasonable assumption, as recent experimentally determined uptake coefficients for 
$\mathrm{HO}_{2}$ on realistic aerosol surfaces range only from $0.01-0.1$ (Thornton et al., 2008; Taketani et al., 2008, 2009). During the summer 2002 NAMBLEX project, which took place at Mace Head on the West coast of Ireland, the role of halogen oxides, specifically $\mathrm{IO}$ and $\mathrm{BrO}$, in the chemistry of the MBL was confirmed (Bloss et al., 2005b; Sommariva et al., 2006; Smith et al., 2006). IO and $\mathrm{BrO}$ react quickly with $\mathrm{HO}_{2}$, with rate coefficients at $25^{\circ} \mathrm{C}$ of 8.6 and $2.1 \times 10^{-11}$ molecule ${ }^{-1} \mathrm{~cm}^{3} \mathrm{~s}^{-1}$ for IO and $\mathrm{BrO}$, respectively (IUPAC, 2006). The HOI and HOBr formed may then either undergo photolysis to yield $\mathrm{OH}$ (and a halogen atom) or be taken up onto an aerosol surface. Reaction of HOI and $\mathrm{HOBr}$ with halide ions in acidified aerosol can form volatile inter-halogen species (Vogt et al., 1996; Pechtl et al., 2007) which photolyse in the gas phase allowing gaseous halogen chemistry to continue. The inclusion of a halogen scheme has been shown to improve the $\mathrm{HO}_{2}$ modelled to measured agreement at a number of marine sites (Bloss et al., 2005b; Smith et al., 2006; Sommariva et al., 2006; Kanaya et al., 2007), and could account for the model discrepancy reported during the SOAPEX-2 experiment if realistic $\mathrm{HO}_{2}$ uptake coefficients were instead used (Haggerstone et al., 2005).

At coastal locations such as Mace Head, the primary source of IO is the photolysis of molecular iodine (SaizLopez and Plane, 2004) and, to a smaller extent, iodocarbons (Chameides and Davis, 1980; Carpenter et al., 1999), which are released by macro-algae exposed at low tide. The iodine atoms generated react rapidly with $\mathrm{O}_{3}$ to generate the $\mathrm{IO}$ radical. At coastal sites where macro-algae are exposed, IO follows a distinct diurnal profile, with concentrations peaking with low tide during the daytime (Alicke et al., 1999; Whalley et al., 2007). The impact of halogens on tropospheric oxidants in regions without tidally exposed macro-algae, for example the open ocean, which covers $\sim 70 \%$ of Earth's surface, was until recently, unconfirmed. A number of theoretical and observational studies had inferred indirectly the possible global impact of halogens (Dickerson et al., 1999; Vogt et al., 1999; Galbally et al., 2000; von Glasow et al., 2002; von Glasow et al., 2004), but observations in the remote MBL were limited (Allan et al., 2000; Leser et al., 2003). In 2006/2007 an 8 month measurement series of IO and $\mathrm{BrO}$ at the Cape Verde Atmospheric Observatory (CVAO) was reported (Read et al., 2008), exhibiting broad diurnal profiles following light intensity; with typical peak concentrations of $\sim 1.4$ and 2.5 pptv, respectively. CVAO is thought to be representative of the open ocean tropical MBL; ship and aircraft measurements confirm that the measurements at the site are representative of the surrounding area (Read et al., 2008; Lee et al., 2009a) and hence these observations suggest a potentially global presence of halogen oxides. Although IO and $\mathrm{BrO}$ are present at much lower concentrations than observed at coastal sites, for example Mace Head $\left([\mathrm{BrO}]_{\max }=6.5 \mathrm{pptv}\right.$; Saiz-Lopez et al., 2004, and [IO $]_{\max } \sim 30 \mathrm{pptv}$; Commane, 2009) and Roscoff, France ( $[\mathrm{IO}]_{\max } \sim 28 \mathrm{pptv}$; Furneaux et al., 2009), the inclusion of bromine and iodine chemistry was necessary to model adequately the daily $\mathrm{O}_{3}$ destruction that is observed at Cape Verde (Read et al., 2008).

For $[\mathrm{NO}]<\sim 20$ pptv, $\mathrm{O}_{3}$, an important greenhouse gas in the troposphere, is photochemically destroyed (Penkett et al., 1997; Lee et al., 2009b) (e.g. via Reactions (R1)-(R4) and as shown in Fig. 1).

$$
\begin{aligned}
& \mathrm{O}_{3}+\mathrm{OH} \rightarrow \mathrm{HO}_{2}+\mathrm{O}_{2} \\
& \mathrm{O}_{3}+\mathrm{HO}_{2} \rightarrow \mathrm{OH}+2 \mathrm{O}_{2}
\end{aligned}
$$

When halogen oxides are present, further $\mathrm{O}_{3}$ destruction may occur via the reaction of a halogen atom $(\mathrm{X})$ with $\mathrm{O}_{3}$ and subsequent reaction of $\mathrm{XO}$ with $\mathrm{HO}_{2}, \mathrm{NO}$, or $\mathrm{XO}$ :

$$
\begin{aligned}
& \mathrm{X}+\mathrm{O}_{3} \rightarrow \mathrm{XO}+\mathrm{O}_{2} \\
& \mathrm{XO}+\mathrm{HO}_{2} \rightarrow \mathrm{HOX}+\mathrm{O}_{2} \\
& \mathrm{HOX}+\mathrm{hv} \rightarrow \mathrm{OH}+\mathrm{X} \\
& \mathrm{XO}+\mathrm{NO} \rightarrow \mathrm{X}+\mathrm{NO}_{2} \\
& \mathrm{XO}+\mathrm{IO} \rightarrow \mathrm{X}+\mathrm{OIO} \\
& \mathrm{XO}+\mathrm{XO} \rightarrow 2 \mathrm{X}+\mathrm{O}_{2}
\end{aligned}
$$

Surface deposition of $\mathrm{O}_{3}$ may also contribute to its destruction in the BL. At higher levels of NO the regime switches to a net $\mathrm{O}_{3}$ production via the following reactions:

$$
\begin{aligned}
& \mathrm{HO}_{2}+\mathrm{NO} \rightarrow \mathrm{OH}+\mathrm{NO}_{2} \\
& \mathrm{RO}_{2}+\mathrm{NO} \rightarrow \mathrm{RO}+\mathrm{NO}_{2} \\
& \mathrm{NO}_{2}+\mathrm{hv}(\lambda<420 \mathrm{~nm}) \rightarrow \mathrm{NO}+\mathrm{O} \\
& \mathrm{O}+\mathrm{O}_{2}+\mathrm{M} \rightarrow \mathrm{O}_{3}+\mathrm{M}
\end{aligned}
$$

Read et al. (2008) reported a consistent daytime $\mathrm{O}_{3}$ destruction cycle at the CVAO with an annually averaged loss of $3.3 \pm 2.6 \mathrm{ppbv} \mathrm{d}^{-1}$. In this paper, we present $\mathrm{OH}$ and $\mathrm{HO}_{2}$ measurements made at the observatory as part of the Reactive Halogen in the Marine Boundary Layer (RHaMBLe) project (Lee et al., 2009a). The contribution towards the overall $\mathrm{O}_{3}$ destruction from the reactions of $\mathrm{OH}$ and $\mathrm{HO}_{2}$ radicals with $\mathrm{O}_{3}$ is determined directly. A detailed model is used to investigate the impact of the reactions of $\mathrm{HO}_{2}$ with $\mathrm{BrO}$ and $\mathrm{IO}$, and the subsequent recycling to $\mathrm{OH}$ via the photolysis of $\mathrm{HOBr}$ and HOI. Of interest is the contribution of halogen chemistry to the rate of photochemical destruction of $\mathrm{O}_{3}$ and the budgets of $\mathrm{OH}$ and $\mathrm{HO}_{2}$ radicals. The significance of halogen chemistry for the global oxidising capacity and hence the removal rate of methane is also examined. 


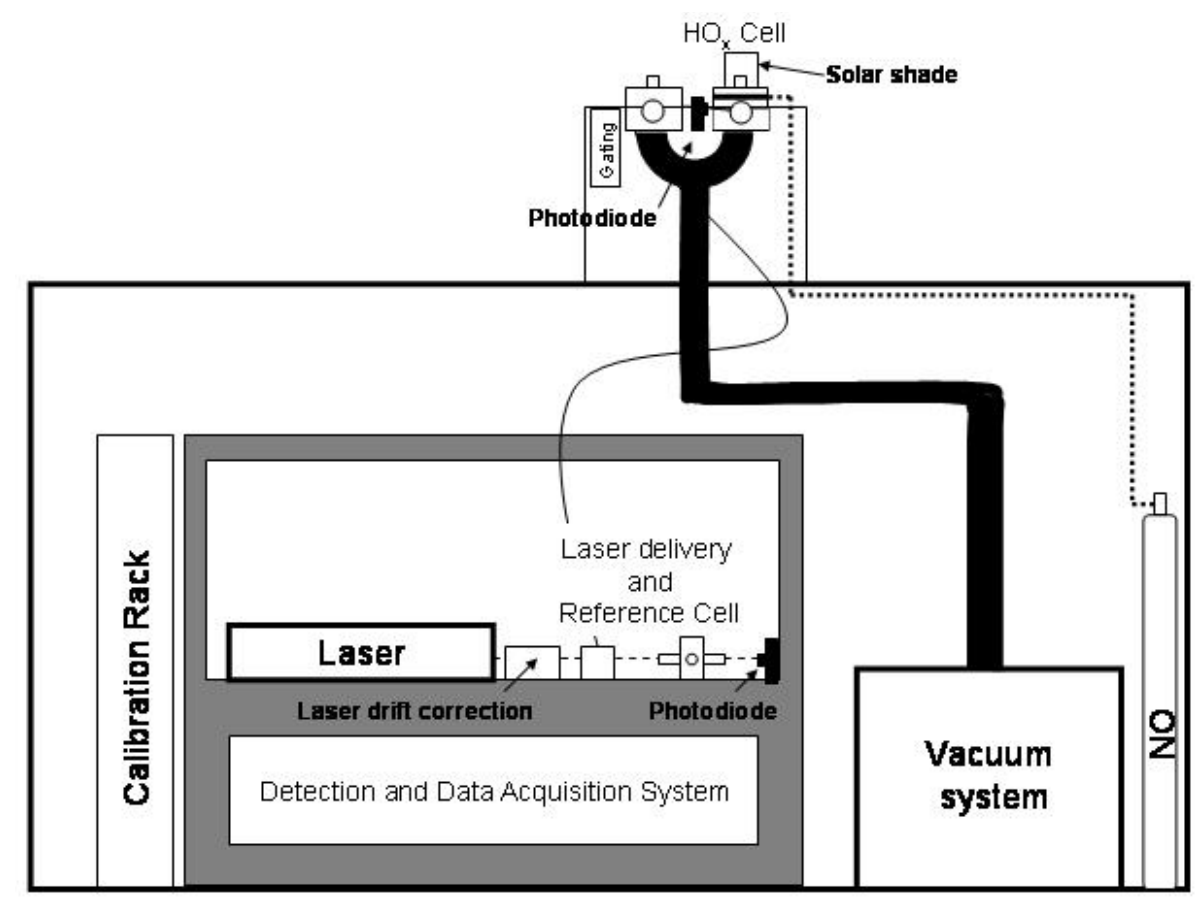

Fig. 2. Schematic of the FAGE laboratory set-up during RHaMBLe (see text for details).

\section{Experimental}

\subsection{Measurement of $\mathrm{OH}$ and $\mathrm{HO}_{2}$ radicals}

Fluorescence Assay by Gas Expansion (FAGE) provides a powerful method for the detection of tropospheric $\mathrm{OH}$ and $\mathrm{HO}_{2}$ radicals (Heard and Pilling, 2003). The technique utilises the strong $\mathrm{A}^{2} \Sigma^{+}\left(\mathrm{v}^{\prime}=0\right) \leftarrow \mathrm{X}^{2} \Pi_{i}\left(\mathrm{v}^{\prime \prime}=0\right) \mathrm{Q}_{1}(2)$ transition at $308 \mathrm{~nm}$ for $\mathrm{OH}$ laser excitation. $\mathrm{HO}_{2}$ can also be detected by this method following initial chemical conversion to $\mathrm{OH}$ by adding $\mathrm{NO}$ and subsequent detection. Laserinduced fluorescence experiments of this type are conducted at low pressures $(\sim 133 \mathrm{~Pa})$ to extend the fluorescence lifetime of the $\mathrm{OH}$ radical sufficiently to allow the fluorescence to be discriminated from the more intense laser radiation. This is achieved by temporal gating of the detector; a channel photo multiplier (CPM) (Perkin Elmer C943P) is used. Switching the CPM off during the laser pulse also helps to prevent detector saturation (Smith et al., 2006). OH fluorescence and scattered light (laser and solar) are recorded by a gated photon counter (SRS SR400) during a $500 \mathrm{~ns}$ integration period (Gate A), commencing approximately $50 \mathrm{~ns}$ after the end of the laser pulse (FWHM $\sim 35 \mathrm{~ns}$ ). A small fraction of the total laser scattered light, along with solar scattered light and detector dark counts constitute a background signal to the $\mathrm{OH}$ fluorescence in gate A. The contribution of the solar scattered light and dark counts can be determined using a second photon counting gate (Gate B), delayed by $50 \mu$ from the first, at a time when the fluorescence and laser pulse have subsided. Tuning the laser away from resonance with the $\mathrm{OH}$ transition (online), to a wavelength where $\mathrm{OH}$ does not absorb (offline), allows the signal contribution of the laser scatter to be determined.

Ambient $\mathrm{OH}$ and $\mathrm{HO}_{2}$ measurements have been made using the University of Leeds ground-based FAGE instrument since 1996 (Heard and Pilling, 2003). Details of the instrument have previously been reported (Smith et al., 2006), and are only considered briefly here. The operating conditions encountered at the CVAO were challenging and a modified operating procedure was necessary. The instrument is housed in an instrumented $20 \mathrm{ft}$ sea container (Fig. 2), and comprises a laser system, an $\mathrm{OH}$ reference cell for calibration of the laser wavelength, fluorescence cells which are housed on the roof of the sea container at a height of $3.5 \mathrm{~m}$, and data acquisition and calibration systems.

During the RHaMBLe project, the instrument was located at the CVAO $\left(16.85^{\circ} \mathrm{N}, 24.87^{\circ} \mathrm{W}\right)$, at Calhau on a northeast facing rocky foreshore on the island of São Vicente within the Cape Verde archipelago. The island shores shelve steeply and very little tidal variability is apparent near to the site. A detailed map of Cape Verde and the layout of the site can be found in Lee et al. (2009a). The site is adjacent to the ocean, the University of Leeds ground-based FAGE instrument was approximately $50 \mathrm{~m}$ from the water's edge and the inlet was positioned approximately $3.5 \mathrm{~m}$ above sea level (a.s.l.). A wavelength tuneable Nd:YAG pumped Ti:Sapphire laser (Photonics Industries DS 20-532) was used to generate UV light at $308 \mathrm{~nm}$. The Nd:YAG produces $\sim 9 \mathrm{~W}$ of 
$532 \mathrm{~nm}$ radiation at a pulse repetition rate of $5 \mathrm{kHz}$, and is used to pump a Ti:Sapphire laser which generates up to $1.6 \mathrm{~W}$ of broadband near-IR radiation. Selecting a wavelength close to $924 \mathrm{~nm}$, by changing the incident angle of an intra-cavity diffraction grating, and frequency tripling, by passing the light through two non-linear harmonic generation stages, generates the required radiation close to $308 \mathrm{~nm}$ for $\mathrm{OH}$ excitation. The time taken for the Ti:Sapphire laser to build up sufficient gain for laser output was found to change significantly in this campaign. When optimally aligned, the delay between the $532 \mathrm{~nm}$ pump pulse and the Ti:Sapphire laser output can be as short as $200 \mathrm{~ns}$, but as laser optics become damaged or alignment shifts (possibly due to temperature changes) this delay can increase. The time between the Ti:Sapphire laser pulse, $t_{308}$, and the time when the fluorescence photons are counted (beginning of gate A) is criti$\mathrm{cal}$, and must be maintained constant to ensure that the instrument sensitivity and background laser scatter does not change. A counter timer (Agilent Technologies, $225 \mathrm{MHz}$ universal counter) triggered at the same time $\left(t_{0}\right)$, as the laser, and coupled to a photodiode (Hamamatsu, S6468 series), which monitors the onset of the pulse of frequency tripled $308 \mathrm{~nm}$ light $\left(t_{308}\right)$, was implemented during this project to measure the delay $t_{308}-t_{0}$. This system allowed any drift in $t_{308}-t_{0}$ to be directly monitored in real time and a correction added to or subtracted from the time of the trigger controlling the start of the fluorescence photon counting gate $\mathrm{A}$. The correction was applied prior to the beginning of each data acquisition cycle, which lasted $\sim 450 \mathrm{~s}$.

During this campaign a number of the optical coatings within the laser became damaged as a result of the high intensity laser beam hitting dust or sea-salt particles that had deposited on the optics. Although this problem occurs, to a certain extent, in all environments, the effect was particularly exacerbated at the CVAO, which is exposed to the elements being close to the water's edge and subject to wind-speeds regularly in excess of $10 \mathrm{~ms}^{-1}$. The resultant optical damage led to a reduction in laser power at $308 \mathrm{~nm}$ from $\sim 40 \mathrm{~mW}$ to $<20 \mathrm{~mW}$ as the project progressed. The stability of the delay time $t_{308}-t_{0}$ was significantly worse than had been observed previously (or since). In addition, tuning the laser wavelength by $0.006 \mathrm{~nm}$ (the interval between the online and offline positions) significantly changed $t_{308}-t_{0}$ and hence the position of gate A relative to the laser. As a result, the laser power and hence the laser scattered light changed significantly between the online and offline positions. The timing drift precluded $\mathrm{OH}$ measurements during the first half of the project, and the $\mathrm{HO}_{2}$ measurements were subject to a larger uncertainty during this period. The timing problem was eventually ameliorated by reducing the interval between the online and offline wavelengths to $0.004 \mathrm{~nm}$, for which the change in $t_{308}-t_{0}$ was much reduced.

Upon exiting the laser, the light was split by a dielectrically coated beam-splitter (CVI Optics Ltd). $80 \%$ was directed to a fluorescence cell via a fibre launcher (Elliot
Gold $^{\mathrm{TM}}$ series), fibre optic (Elliot Scientific) and collimation assembly (Oz Optics), and 19\% to an OH reference cell, designed to aid the precise tuning of the laser wavelength to the peak of the $\mathrm{Q}_{1}(2) \mathrm{OH}$ transition. A large concentration of $\mathrm{OH}$ is generated by the pyrolysis of $\mathrm{H}_{2} \mathrm{O}$ vapour, using a flow of humidified air over a heated filament. Light exiting the reference cell was directed on a UV sensitive photodiode (New Focus 2032) to determine the laser power for subsequent normalisation of the ambient LIF signal; a cut-off filter was placed in front of the photodiode to prevent visible light reaching it. The remaining UV light (1\%) was directed onto a fast photodiode (Hamamatsu, S6468 series), which was used as input to the counter-timer to correct for any drift in the laser timing.

The laser light entered the detection cell on the roof of the container via a baffled side arm and intersected the ambient air stream, drawn through a $0.8 \mathrm{~mm}$ diameter nozzle sat on a $25 \mathrm{~mm}$ turret, on an axis perpendicular to the fluorescence detection axis containing the CPM. The laser light then exited the cell via a second baffled side arm and was reflected onto a second UV sensitive filtered photodiode (New Focus 2032), the output of which was monitored to check good laser alignment was being maintained through the cell. Ambient temperature fluctuations can cause the voltage output from photodiodes to drift, this precludes the use of the detection cell photodiode (located on the roof) to normalise the LIF signal to laser power. High solar intensities were experienced at the Cape Verde site (the solar zenith angle at solar noon in June at the site was $\sim 5^{\circ}$ ) leading to a large amount of solar scattered light detected within the cell by the CPM. A solar shade, consisting of a sheet of black aluminium $(10 \mathrm{~cm} \times 10 \mathrm{~cm})$ was placed $15 \mathrm{~cm}$ above the nozzle, which reduced the solar counts that reached the detector by an order of magnitude. Without the shade, solar counts at solar noon could reach $>200$ counts s$^{-1}$, the random fluctuations of which are larger than the typical signal from $\mathrm{OH}$, making measurements extremely difficult. The windspeed at the site was $\sim 10 \mathrm{~ms}^{-1}$ (and rarely dropped below $5 \mathrm{~ms}^{-1}$ ), thus the average time an air parcel spent under the shade was $\sim 0.01 \mathrm{~s}$, much shorter than the lifetime of either $\mathrm{OH}$ or $\mathrm{HO}_{2}$ radicals, and should not perturb their concentrations.

Normally, the University of Leeds ground-based FAGE instrument utilises two fluorescence cells for simultaneous $\mathrm{OH}$ and $\mathrm{HO}_{2}$ measurements (Smith et al., 2006). Due to low laser power, coupled with a CPM failure in the $\mathrm{OH}$ cell, however, only one cell was operable during the project and was used instead to make alternating sequential measurements of the two radicals. This set-up has been successfully utilised on a number of previous field projects, for example during the recent CHABLIS project (Bloss et al., 2007). Signals from the photon counter were integrated for $1 \mathrm{~s}$ periods. Online data were acquired for $200 \mathrm{~s}$ and consisted of $100 \mathrm{~s}$ of fluorescence from $\mathrm{OH}$, followed by $100 \mathrm{~s}$ of fluorescence from both $\mathrm{OH}$ and converted $\mathrm{HO}_{2}$ (NO added to the cell). The offline signal was then collected for a further period of $100 \mathrm{~s}$, with 
NO added after $50 \mathrm{~s}$ to measure any additional signal caused by the addition of $\mathrm{NO}$, for example from enhanced scattering (there was no extra signal). The $[\mathrm{OH}]$ did not vary significantly during a single data acquisition period, and, therefore, the signal due to $\mathrm{HO}_{2}$ could be determined by subtracting the $\mathrm{OH}$ online signal from the $\mathrm{HO}_{\mathrm{x}}$ online signal. In total, one data acquisition cycle (including the time taken to find the peak of the $\mathrm{OH}$ transition) took $\sim 450 \mathrm{~s}$.

Calibrations were performed every two to three days throughout the campaign. A zero air generator (EcoPhysics PAG 003) was coupled to a zero air trap (Megatech CE500KF-O-4R Gas Purifier) which reduced the levels of $\mathrm{NO}_{\mathrm{x}}$, VOCs and $\mathrm{CO}$ to $<1 \mathrm{pptv}$ and following humidification in a liquid water bubbler, this flow was directed down a $60 \mathrm{~cm}$ long quartz glass tube (internal diameter $22 \mathrm{~cm}$ ) past a Hg pen-ray lamp (LOT Oriel model 6035), under roughly laminar flow conditions (Reynolds Number $=646$ ). The $184.9 \mathrm{~nm}$ radiation emitted by the pen-ray lamp photolysed $\mathrm{H}_{2} \mathrm{O}$ vapour, generating $\mathrm{OH}$ and $\mathrm{HO}_{2}$ (in the presence of $\mathrm{O}_{2}$ ) in equal quantities. A few ppbv of $\mathrm{O}_{3}$ was generated from $\mathrm{O}_{2}$ photolysis and the subsequent $\mathrm{O}+\mathrm{O}_{2}$ recombination reaction, and this was used as a chemical actinometer for the $184.9 \mathrm{~nm}$ flux. When calibrating for $\mathrm{HO}_{2}$ a $100 \mathrm{sccm}$ flow of $\mathrm{CO}$ (BOC, $1 \% \mathrm{CO}$ in $\mathrm{N}_{2}$ ) was added to the humidified air flow to rapidly convert all $\mathrm{OH}$ radicals to $\mathrm{HO}_{2}\left(\sim 2.5 \times 10^{-3} \mathrm{~s} \mathrm{OH}\right.$ lifetime). Approximately $5 \mathrm{slm}$ of the central portion of the flow within the tube was drawn into the detection cell, via the $0.8 \mathrm{~mm}$ sampling nozzle, the excess flow $(\sim 7 \mathrm{slm})$ was directed towards an $\mathrm{O}_{3}$ analyser (Thermo Environmental Instruments - TEI - 42C) and Dewpoint Hygrometer (General Eastern 1311DR sensor). Determining $\left[\mathrm{H}_{2} \mathrm{O}\right]$ and $\left[\mathrm{O}_{3}\right]$ enabled the radical concentration to be calculated using:

$[\mathrm{OH}]=\left[\mathrm{HO}_{2}\right]=\frac{\left[\mathrm{O}_{3}\right]\left[\mathrm{H}_{2} \mathrm{O}\right] \sigma_{\mathrm{H}_{2} \mathrm{O}} \phi_{\mathrm{HO}_{\mathrm{x}}}}{\left[\mathrm{O}_{2}\right] \sigma_{\mathrm{O}_{2}} \phi_{\mathrm{O}_{3}} P}$

where $\sigma_{\mathrm{H}_{2} \mathrm{O}}$ and $\sigma_{\mathrm{O}_{2}}$ are the $184.9 \mathrm{~nm}$ absorption cross sections of $\mathrm{H}_{2} \mathrm{O}$ vapour and $\mathrm{O}_{2}$, determined experimentally to be $(7.1 \pm 0.2) \times 10^{-20}$ molecule ${ }^{-1} \mathrm{~cm}^{2}$ and $(1.37 \pm 0.14) \times 10^{-20}$ molecule ${ }^{-1} \mathrm{~cm}^{2}$, respectively, for the same pen-ray lamp used during the field measurements. $\phi_{\mathrm{HO}_{\mathrm{x}}}=1$ is the quantum yield for production of $\mathrm{OH}$ or $\mathrm{HO}_{2}$ in the absence of added $\mathrm{CO}$, and $\phi_{\mathrm{HO}_{\mathrm{x}}}=2$ for $\mathrm{HO}_{2}$ in the presence of added CO. $P$ is the profile factor, which is discussed further below. With the pen-ray lamp switched off $\left(\left[\mathrm{HO}_{\mathrm{x}}\right]=0\right)$ it was found that there was no additional signal above the background when NO was added to the FAGE cell, ruling out the presence of any significant artefact due to $\mathrm{HO}_{\mathrm{x}}$ production either directly from photolysis of impurities (e.g. $\left.\mathrm{HNO}_{3}\right)$ in the $\mathrm{NO}$, or from the photolysis of species desorbed from the walls after exposure to NO.

A correction needs to be applied to account for the parabolic distribution of radial flow velocities across the calibration tube under laminar flow conditions. The central portion of the flow sampled by the detection cell has a higher velocity and hence spends less time in the photolysis region compared with the remainder of the flow (excess) that is sampled by the $\mathrm{O}_{3}$ analyser from regions of the tube with a lower velocity. This radial flow distribution leads to more $\mathrm{O}_{3}$ in the excess air relative to that in the FAGE sampled air at the centre. Any variability in the flux of the $184.9 \mathrm{~nm}$ light across the tube can also perturb the $\mathrm{O}_{3}$ and radical profile in the tube. The profile factor, defined as $P=\left[\mathrm{O}_{3}\right]_{\text {excess }} /\left[\mathrm{O}_{3}\right]_{\text {central }}$, has been experimentally measured as $1.57 \pm 0.09$ (Smith, 2007), and is used in Eq. (1) to calculate $[\mathrm{OH}]$ and $\left[\mathrm{HO}_{2}\right]$.

The sensitivity of the cell towards $\mathrm{OH}$ and $\mathrm{HO}_{2}$, in units of cts $\mathrm{s}^{-1} \mathrm{~mW}^{-1}$ molecule ${ }^{-1} \mathrm{~cm}^{3}$, is given by:

$C_{\mathrm{OH}}=\frac{S_{\mathrm{OH}}}{[\mathrm{OH}] \times P w r}$ and $C_{\mathrm{HO}_{2}}=\frac{S_{\mathrm{HO}_{2}}}{\left[\mathrm{HO}_{2}\right] \times P w r}$

$S_{\mathrm{OH}}$ and $S_{\mathrm{HO}_{2}}$ are the measured fluorescence signals $\left(\mathrm{cts} \mathrm{s}^{-1}\right.$ ) due to $\mathrm{OH}$ (in the absence of added $\mathrm{CO}$ and NO) and $\mathrm{HO}_{2}$ (in the presence of added $\mathrm{CO}$ and $\mathrm{NO}$ ), respectively. $P w r$ is the laser power entering the cell in $\mathrm{mW}$, which decreased from $\sim 19$ to $\sim 7 \mathrm{~mW}$ during the RHaMBLe campaign. The average instrument sensitivity was $1.1 \times 10^{-7} \mathrm{cts} \mathrm{s}^{-1} \mathrm{~mW}^{-1}[\mathrm{OH}]^{-1}$ for $\mathrm{OH}$ and $4.4 \times 10^{-8} \mathrm{cts} \mathrm{s}^{-1} \mathrm{~mW}^{-1}\left[\mathrm{HO}_{2}\right]^{-1}$ for $\mathrm{HO}_{2}$, with the $2 \sigma$ uncertainty estimated as $\sim 40 \%$ for $\mathrm{OH}$ and $\mathrm{HO}_{2}$ (Smith, 2007). The cell pressure was optimised for $\mathrm{OH}$ detection rather than for conversion of $\mathrm{HO}_{2}$. The detection limit (LOD) is given by:

$\mathrm{LOD}=\frac{\mathrm{SNR}}{P w r \times C} \sqrt{\left(\frac{1}{m}+\frac{1}{n}\right) \frac{S_{\text {back }}}{t}}$

where SNR is the signal-to-noise ratio (1), $m$ is the number of online data points (100), $n$ is the number of offline points (50), $S_{\text {back }}$ is the background signal comprising laser scattered light $\left(\sim 20 \mathrm{cts} \mathrm{s}^{-1}\right)$, solar scattered light (max. $\sim 20 \mathrm{cts} \mathrm{s}^{-1}$ at noon) and CPM dark counts $\left(0 \mathrm{cts} \mathrm{s}^{-1}\right)$ and $t$ is the integration of each data point (1 s). Using the above values and $P w r=9 \mathrm{~mW}$, LODs of $1.1 \times 10^{6}$ molecule $\mathrm{cm}^{-3}$ and $2.8 \times 10^{6}$ molecule $\mathrm{cm}^{-3}$ were calculated for $\mathrm{OH}$ and $\mathrm{HO}_{2}$, respectively.

\subsection{Ancillary measurements}

A number of ancillary measurements were made to permit a detailed characterisation of the atmospheric composition at the site and to constrain the box model. Details of these measurements are listed in Table 1 and are discussed further in Lee et al. (2009a). The majority of these measurements are part of a long term dataset made continuously at the Cape Verde Observatory since October 2006. The halogen oxide measurements made using Long Path-Differential Optical Absorption Spectroscopy (LP-DOAS) were part of an 8 month dataset, covering the period November 2006 to June 2007 (Read et al., 2008). 
Table 1. Listing of the concurrent measurements made during the RHaMBLe project and used to constrain the box model.

\begin{tabular}{|c|c|c|c|c|c|}
\hline Measurements & Instrument & $\begin{array}{l}\text { Typical noon } \\
\text { value }\end{array}$ & $\begin{array}{l}\text { Averaging } \\
\text { Time }\end{array}$ & $\begin{array}{l}\text { LOD } \\
(2 \sigma)\end{array}$ & Reference \\
\hline $\mathrm{O}_{3}$ & TEI 42c, UV absorption & $35 \mathrm{ppbv}$ & $1 \mathrm{~min}$ & $1 \mathrm{ppbv}$ & (Lee et al., 2009a) \\
\hline $\mathrm{CO}$ & Aerolaser, VUV resonance fluorescence & $104 \mathrm{ppbv}$ & $1 \mathrm{~min}$ & - & (Lee et al., 2009a) \\
\hline $\mathrm{CH}_{4}$ & Flask Samples, Gas Chromatography analysis & $1821 \mathrm{ppbv}$ & - & - & (Lee et al., 2009a) \\
\hline NO & Chemiluminesence detector & $2.3 \mathrm{pptv}$ & $1 \mathrm{~h}$ & $1.5 \mathrm{pptv}$ & (Lee et al., 2009b) \\
\hline $\mathrm{NO}_{2}$ & Chemiluminesence detector & $11 \mathrm{pptv}$ & $1 \mathrm{~h}$ & $4.1 \mathrm{pptv}$ & (Lee et al., 2009b) \\
\hline Ethane & $\begin{array}{l}\text { Gas Chromatography- Flame Ionisation Detection } \\
\text { (GC-FID) }\end{array}$ & $845 \pm 26 \mathrm{pptv}$ & $1 \mathrm{~h}$ & $2.5 \mathrm{pptv}$ & (Read et al., 2009) \\
\hline Propane & GC-FID & $50 \pm 1.7 \mathrm{pptv}$ & $1 \mathrm{~h}$ & 2.5 pptv & (Read et al., 2009) \\
\hline Iso-butane & GC-FID & $2.2 \pm 0.2 \mathrm{pptv}$ & $1 \mathrm{~h}$ & $2.5 \mathrm{pptv}$ & (Read et al., 2009) \\
\hline n-butane & GC-FID & $3.9 \pm 0.3$ pptv & $1 \mathrm{~h}$ & $2.5 \mathrm{pptv}$ & (Read et al., 2009) \\
\hline Acetylene & GC-FID & $119 \pm 3.3 \mathrm{pptv}$ & $1 \mathrm{~h}$ & $2.5 \mathrm{pptv}$ & (Read et al., 2009) \\
\hline Ethene & GC-FID & $21 \pm 1.4$ pptv & $1 \mathrm{~h}$ & $2.5 \mathrm{pptv}$ & (Read et al., 2009) \\
\hline Propene & GC-FID & $22 \pm 0.9 \mathrm{pptv}$ & $1 \mathrm{~h}$ & $2.5 \mathrm{pptv}$ & (Read et al., 2009) \\
\hline Isoprene & GC-FID & $10 \pm 1.0 \mathrm{pptv}$ & $1 \mathrm{~h}$ & $1.0 \mathrm{pptv}$ & (Read et al., 2009) \\
\hline Acetaldehyde & GC-FID & $826 \pm 137 \mathrm{pptv}$ & $1 \mathrm{~h}$ & $18 \mathrm{pptv}$ & (Read et al., 2009) \\
\hline Methanol & GC-FID & $749 \pm 115 \mathrm{pptv}$ & $1 \mathrm{~h}$ & $7 \mathrm{pptv}$ & (Read et al., 2009) \\
\hline Acetone & GC-FID & $487 \pm 45$ pptv & $1 \mathrm{~h}$ & 3 pptv & (Read et al., 2009) \\
\hline IO & LP-DOAS & $1.3 \mathrm{pptv}$ & 20-30 min & $0.3-0.5 \mathrm{pptv}$ & (Read et al., 2008) \\
\hline $\mathrm{BrO}$ & LP-DOAS & $2.9 \mathrm{pptv}$ & $20-30 \mathrm{~min}$ & $0.5-1$ pptv & (Read et al., 2008) \\
\hline $\mathrm{HCHO}$ & LP-DOAS & $328 \mathrm{pptv}$ & $20-30 \mathrm{~min}$ & 200 pptv & $\begin{array}{l}\text { (Mahajan et al., } \\
\text { 2010) }\end{array}$ \\
\hline $\mathrm{J}\left(\mathrm{O}^{1} \mathrm{D}\right)$ & Filter Radiometer & $3.4 \times 10^{-5} \mathrm{~s}^{-1 a}$ & $1 \mathrm{~min}$ & - & (Lee et al., 2009a) \\
\hline Aerosol & $\begin{array}{l}\text { Scanning Mobility Particle Sizer (SMPS) \& } \\
\text { Aerosol Particle Sizer (APS) }\end{array}$ & $1 \times 10^{-6} \mathrm{~cm}^{2} \mathrm{~cm}^{-3}$ & $30 \mathrm{~min}$ & - & (Allan et al., 2009) \\
\hline $\begin{array}{l}\text { Relative } \\
\text { Humidity }\end{array}$ & Campbell Met Station & $76 \%$ & $1 \mathrm{~min}$ & - & (Lee et al., 2009a) \\
\hline Temperature & Campbell Met Station & $296 \mathrm{~K}$ & $1 \mathrm{~min}$ & - & (Lee et al., 2009a) \\
\hline Pressure & Campbell Met Station & $1016 \mathrm{hPa}$ & $1 \mathrm{~min}$ & - & (Lee et al., 2009a) \\
\hline
\end{tabular}

\subsection{Box model using the master chemical mechanism}

A box model was used to calculate $\mathrm{OH}$ and $\mathrm{HO}_{2}$ concentrations, and contained a near explicit chemical scheme for the oxidative degradation of $\mathrm{C} 1-\mathrm{C} 5$ hydrocarbons, extracted from the Master Chemical Mechanism (MCM) version 3.1 (Saunders et al., 2003). The entire MCM treats the degradation of $135 \mathrm{VOCs}$ and considers oxidation by $\mathrm{OH}, \mathrm{O}_{3}$ and $\mathrm{NO}_{3}$. The degradation continues until $\mathrm{CO}_{2}$ and $\mathrm{H}_{2} \mathrm{O}$ vapour form as the final oxidation products. Complete details of the kinetic and photochemical data used in the mechanism are available at the MCM website (MCM, http://mcm.leeds.ac.uk/MCM/home). A halogen chemical scheme (listed in supplementary information: http://www.atmos-chem-phys.net/10/1555/2010/ acp-10-1555-2010-supplement.pdf) was added to the MCM to assess the effect of $\mathrm{IO}, \mathrm{BrO}$ and related species on the budgets of $\mathrm{OH}, \mathrm{HO}_{2}$ and $\mathrm{O}_{3}$ concentrations. The mechanism contains photolysis of $\mathrm{O}_{3}, \mathrm{NO}_{2}, \mathrm{HOI}, \mathrm{HOBr}$, IO, aldehydes, ketones, $\mathrm{H}_{2} \mathrm{O}_{2}$ and organic hydroperoxides $\left(\mathrm{RO}_{2} \mathrm{H}\right)$, but only measurements of $j\left(\mathrm{O}^{1} \mathrm{D}\right)$ were used to constrain the model. The other photolysis rates were calculated based on a two- stream scattering model (Hough, 1988) and assuming clearsky conditions. Under cloudy conditions calculated $J$ values were scaled to the ratio of observed $j\left(\mathrm{O}^{1} \mathrm{D}\right)$ to clear sky $j\left(\mathrm{O}^{1} \mathrm{D}\right)$. Dry deposition terms for $\mathrm{H}_{2} \mathrm{O}_{2}\left(1 \mathrm{~cm} \mathrm{~s}^{-1}\right)$ (Junkermann and Stockwell, 1999), $\mathrm{RO}_{2} \mathrm{H}\left(0.9 \mathrm{~cm} \mathrm{~s}^{-1}\right)$ (Junkermann and Stockwell, 1999), $\mathrm{HNO}_{3}\left(0.8 \mathrm{~cm} \mathrm{~s}^{-1}\right)$ (Ganzeveld and Lelieveld, 1995), $\mathrm{CH}_{3} \mathrm{OH}\left(0.09 \mathrm{~cm} \mathrm{~s}^{-1}\right)$ (Carpenter et al., 2004) and HCHO and aldehydes $\left(0.33 \mathrm{~cm} \mathrm{~s}^{-1}\right)$ (Brasseur et al., 1998) were included in the model. The model was constrained to hourly measurements of a number of VOCs (listed explicitly in Table 1), $\mathrm{NO}_{\mathrm{x}}, \mathrm{O}_{3}, \mathrm{CO}, \mathrm{CH}_{4}, j\left(\mathrm{O}^{1} \mathrm{D}\right)$ and meteorological parameters. The midday concentrations/values of these model constraints are given in Table 1 for information; there were, however, some deviations from these typical midday values in the hourly measurements that were used as model inputs. The halogen scheme was constrained using measurements of the diurnal cycle of $[\mathrm{IO}]$ and $[\mathrm{BrO}]$ averaged for May 2007. It was necessary to use an average because of incomplete data coverage primarily arising from IO and $\mathrm{BrO}$ being detected by DOAS in different wavelength regions and, therefore, not being measured simultaneously. A $\mathrm{H}_{2}$ concentration of $500 \mathrm{ppbv}$ was used, similar to that 
measured in the remote MBL at other locations, for example during SOAPEX-2 at Cape Grim (Sommariva et al., 2004), and used in $\mathrm{OH}$ model calculations during the ALBATROSS campaign (Brauers et al., 2001). A constant HCHO concentration of $328 \mathrm{pptv}$ was assumed in the base-case model scenario, based on average [HCHO] measured by LP-DOAS during May at the observatory (Mahajan et al., 2010). Deviations from this background [HCHO] used (and the impact upon $\mathrm{HO}_{\mathrm{x}}$ levels) are considered in Sect. 3.4. The unmeasured intermediate species, generated from the oxidation of VOCs and other species used to constrain the model, were initialised at zero. The simultaneous rate equations were solved using the FACSIMILE integrator (Curtis and Sweetenham, 1987). The model was allowed to run to steady state ( $\sim 4$ days) to stabilise the concentrations of any unmeasured intermediate species, e.g. alkyl nitrates, unmeasured carbonyls and peroxides, before the $\mathrm{OH}$ and $\mathrm{HO}_{2}$ modelled data were compared to the measurements.

The rate of heterogeneous loss of $\mathrm{HO}_{2}$ and a number of halogenated species (supplementary information: http://www.atmos-chem-phys.net/10/1555/2010/ acp-10-1555-2010-supplement.pdf) to aerosol surfaces has been included in the model. A simple scheme was used, based on a first-order loss to aerosol surfaces (Ravishankara, 1997):

$k^{\prime}$ loss $=\frac{c_{\mathrm{g}} A \gamma}{4}$

where $c_{g}$ is the mean molecular speed of the gas molecules $\left(\mathrm{cm} \mathrm{s}^{-1}\right)$, calculated using Eq. (5):

$c_{\mathrm{g}}=\sqrt{\frac{8 R T}{\pi M_{\mathrm{w}}}}$

$k^{\prime}$ loss is the heterogeneous loss rate, $A$ is the aerosol surface area per unit volume, $\gamma$ is the uptake coefficient, $R$ is the universal gas constant, $T$ is temperature and $M_{\mathrm{w}}$ is the molecular weight of the gas. More recently, this scheme was extended by Sommariva et al. (2006) and Haggerstone et al. (2005) to incorporate loss rates that were dependent upon the measured aerosol size-distribution, using an expression which incorporated the transition between control by gasphase diffusion and molecular uptake (Sander, 1999). In the background marine environment, the particle diameters are small. Under such conditions, mass transfer is limited by interfacial mass transport and Eq. (4) provides a reasonable estimation of the aerosol uptake coefficient (Haggerstone et al., 2005).

The particle radius and number population, used to determine the aerosol surface area, were measured with a Scanning Mobility Particle Sizer (SMPS) $(0-1 \mu \mathrm{m})$ and a Aerosol Particle Sizer (APS) $(1-10 \mu \mathrm{m})$ (Allan et al., 2009) at a height of $30 \mathrm{~m}$. The average aerosol surface area observed at the CVAO at this height during the project was $\sim 1 \times 10^{-6} \mathrm{~cm}^{2} \mathrm{~cm}^{-3}$. For particles of $0-1 \mu \mathrm{m}$ diameter (which encompasses the bulk of the aerosols at the site) a dry aerosol distribution was determined. At an average ambient humidity of $\sim 80 \%$ the radius of sea-salt aerosols are expected to grow by a factor of $\sim 1.4$ (Allan et al., 2009), leading to an ambient aerosol surface area of roughly a factor of 2 ( (adius $^{2}$ ) larger for this size range. A strong gradient in the aerosol surface area at the ground to a height of $\sim 12 \mathrm{~m}$ has recently been recorded at the site (von Glasow, 2009). It is estimated from these gradient measurements that the aerosol surface area is approximately a factor of 2 greater at the height of the FAGE nozzle $(\sim 3.5 \mathrm{~m})$ compared with the aerosol surface area at $30 \mathrm{~m}$. To account for the difference in sampling height and aerosol growth factors an aerosol surface area of $4 \times 10^{-6} \mathrm{~cm}^{2} \mathrm{~cm}^{-3}$ was used in model calculations. An uptake coefficient $(\gamma)$ of 0.1 was used based on recent recommendations (Taketani et al., 2008). Sensitivity analyses have been performed on the aerosol uptake (see Sect. 3.4 for further details).

A surface deposition term for $\mathrm{HO}_{2}$ was also considered. The deposition velocity $\left(V_{\mathrm{D}}\right)$ of $\mathrm{HO}_{2}$ was estimated using the NOAA/COARE air/sea gas exchange parameterization (Fairall et al., 2007). The deposition velocity of $\mathrm{HO}_{2}$ is related to the flux $(F)$ of $\mathrm{HO}_{2}$ at a given height above the surface $(z)$ by:

$F=-V_{\mathrm{D}} \times\left[\mathrm{HO}_{2}\right]_{(z)}$

$V_{\mathrm{D}}$ can be determined given knowledge of the sum of air-side $\left(R_{\mathrm{a}}\right)$ and water-side $\left(R_{\mathrm{W}}\right)$ resistances (Fairall et al., 2000):

$V_{\mathrm{D}}=\left(\frac{1}{R_{\mathrm{a}}+\left(R_{\mathrm{w}} / \alpha\right)}\right)$

where $\alpha$ is the dimensionless solubility (a function of species, temperature and salinity). The air-side resistance, $R_{\mathrm{a}}$, represents the sum of the aerodynamic resistance $\left(R_{1}\right)$ and gasphase film resistance $\left(R_{2}\right)$. Assuming that the atmospheric surface layer is neutrally stable then $R_{1}$ can be determined using Eq. (8):

$R_{1}=\frac{U_{(z)}}{u_{*}^{2}}=\frac{1}{\kappa u_{*}} \ln \left(\frac{z}{z_{0}}\right)$

where $U_{(z)}$ is the mean wind-speed at height $(z), \kappa$ is the von Karman constant $(0.4), u_{*}$, is the friction velocity, and $z_{0}$, is the aerodynamic roughness length (Stull, 1988). The gas-phase film resistance $\left(R_{2}\right)$ is determined by Eq. (9):

$R_{2}=\frac{5}{u_{*}} S_{\mathrm{C}}^{2 / 3}$

where $S_{\mathrm{C}}$ is the Schmidt number.

The water-side resistance $\left(R_{\mathrm{w}}\right)$ can be determined by Eq. (10) (assuming the influence of turbulence is negligible relative to chemical reaction time-scale of $\mathrm{HO}_{2}$ in water):

$R_{\mathrm{w}}=\frac{1}{\sqrt{a D_{\mathrm{w}}}}$ 

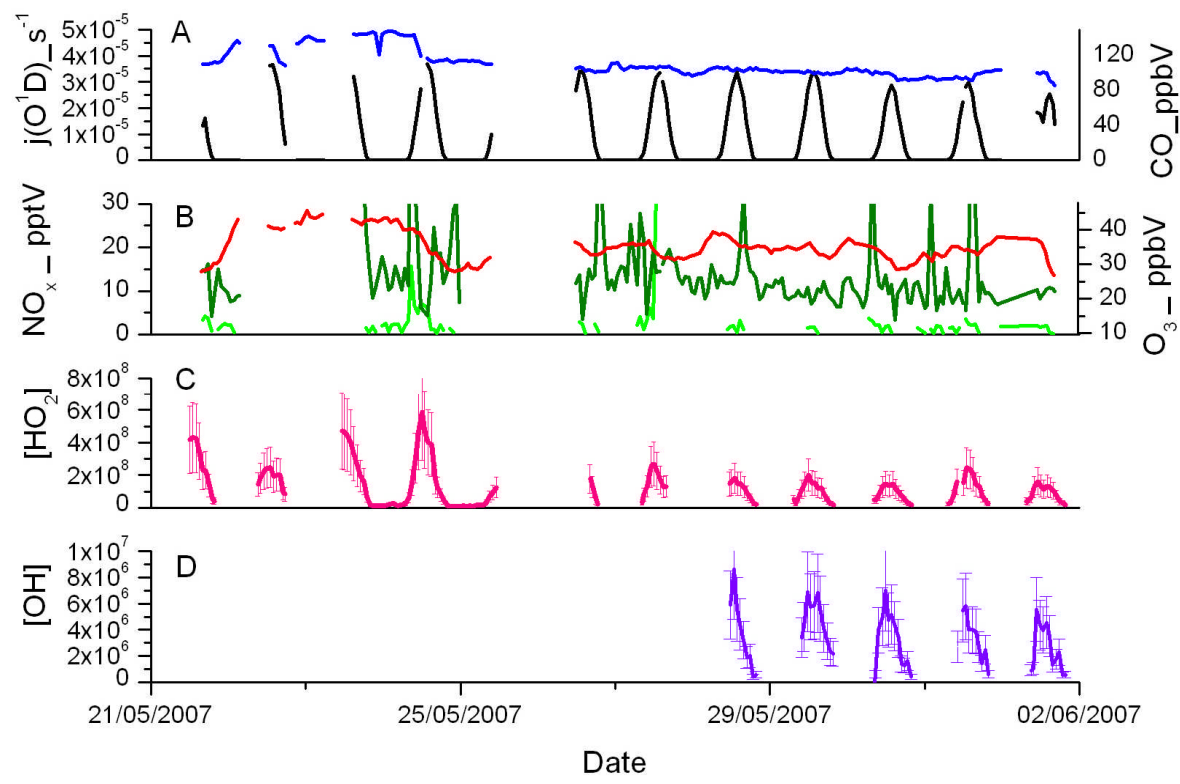

Fig. 3. Panel (A): Time-series of $j\left(\mathrm{O}^{1} \mathrm{D}\right)$ (black line) and $\mathrm{CO}$ (blue line) from the $\mathrm{HO}_{\mathrm{x}}$ measurement period (gaps in data are due to power failures). Panel (B): Time-series of $\mathrm{NO}$ (lime line), $\mathrm{NO}_{2}$ (green line) and $\mathrm{O}_{3}$ (red line) from the $\mathrm{HO}_{\mathrm{x}}$ measurement period (gaps in data are due to power failures or instrument down-time). Panel (C): Time-series of measured $\mathrm{HO}_{2}$ in molecule $\mathrm{cm}^{-3}$ (pink line) with the $2 \sigma$ standard deviation shown. Panel (D): Time-series of measured $\mathrm{OH}$ in molecule $\mathrm{cm}^{-3}$ (purple line) with the $2 \sigma$ standard deviation shown. All data are hourly averaged.

where $a$ is the reaction time-scale for $\mathrm{HO}_{2}$ in water (assumed to be sufficiently fast that turbulence is neglected) and $D_{\mathrm{w}}$ is the diffusion coefficient of $\mathrm{HO}_{2}$ in water.

Many of the variables in Eqs. (7)-Eq. (10) can be estimated by the NOAA/COARE algorithm given an input of boundary layer depth $(\sim 1000 \mathrm{~m})$ (Read et al., 2008), atmospheric pressure $(\sim 1010 \mathrm{mbar})$, wind-speed $\left(0-20 \mathrm{~m} \mathrm{~s}^{-1}\right)$, height of wind-speed data $(10 \mathrm{~m})$, Henry's law coefficient $\left(1.2 \times 10^{3} \mathrm{M} \mathrm{atm}^{-1}\right.$ (Schwartz, 1984)) and rate coefficients for reactions of $\mathrm{HO}_{2}$ in water (ionisation of $\mathrm{HO}_{2}$ forming $\mathrm{O}_{2}^{-}$and $\mathrm{H}^{+}$; Bielski, 1978, and chemical reaction of $\mathrm{HO}_{2}$ with $\mathrm{O}_{2}^{-}$forming $\mathrm{HO}_{2}^{-}$; Bielski, 1978, were considered). The water-side Schmidt number and diffusion coefficient were assumed to be similar to those of $\mathrm{O}_{3}$ (500 and $1.2 \times 10^{-9} \mathrm{~m}^{2} \mathrm{~s}^{-1}$; Chang et al., 2004). The $\mathrm{HO}_{2}$ water-side reaction rate was varied from $10^{3}-10^{5} \mathrm{~s}^{-1}$ to determine the sensitivity of $V_{\mathrm{D}}$ to it. For $\mathrm{HO}_{2}$, the solubility is sufficiently large that the deposition velocity is essentially air-side controlled and the flux is insensitive to the water side turbulence and reaction rate.

\section{Results}

Figure 3 shows the values of $j\left(\mathrm{O}^{1} \mathrm{D}\right), \mathrm{CO}, \mathrm{NO}, \mathrm{NO}_{2}, \mathrm{O}_{3}$, $\mathrm{HO}_{2}$ and $\mathrm{OH}$ measured at the CVAO during the summer 2007 campaign. $\mathrm{OH}$ measurements were made on 5 days (28 May to 2 June) and $\mathrm{HO}_{2}$ on 11 days (21 May to 2 June). From 21 May-24 May, the air-mass intercepted was characterised by elevated levels of $\mathrm{CO}(\sim 130 \mathrm{ppbv})$; CO levels dropped to $\sim 100$ ppbv during the day on 24 May and remained at this level for the remainder of the radical measurement period (Fig. 3a). Back trajectory analysis for this period indicates a switch in air-mass origin (Lee et al., 2009a). From 2124 May, the air intercepted had originated (at a low altitude) over the western north Atlantic and continental America before being transported at a higher altitude over the ocean and descending close to the Cape Verde islands. From 2629 May the air sampled originated over Southern Europe and the Mediterranean (usually within the boundary layer), before passing near to the Canary Islands on its way to Cape Verde. $[\mathrm{CO}]$ remained at background levels $(\sim 100 \mathrm{ppbv})$ between 26-29 May suggesting that this air-mass was not strongly influenced by anthropogenic emissions from $\mathrm{Eu}-$ rope. From 30 May onwards, the CVAO largely sampled air that was mid north Atlantic in origin, passing close to the Canary Islands before approaching Cape Verde from a North Easterly direction. Throughout the measurement period the maximum noontime $j\left(\mathrm{O}^{1} \mathrm{D}\right)$ levels were relatively constant, at $3.5 \times 10^{-5} \mathrm{~s}^{-1}$ (Fig. 3a) with very little cloud cover observed throughout the campaign. $\mathrm{O}_{3}$ concentrations between 35-40 ppbv were recorded (Fig. 3b) (Lee et al., 2009a).

\subsection{Daytime measured and modelled $\mathrm{OH}$ and $\mathrm{HO}_{2}$}

During 3 out of the first 4 days of measurements $\left[\mathrm{HO}_{2}\right]$ was elevated relative to data taken later in the campaign, corresponding to the elevated $\mathrm{CO}$ during this time, with a 


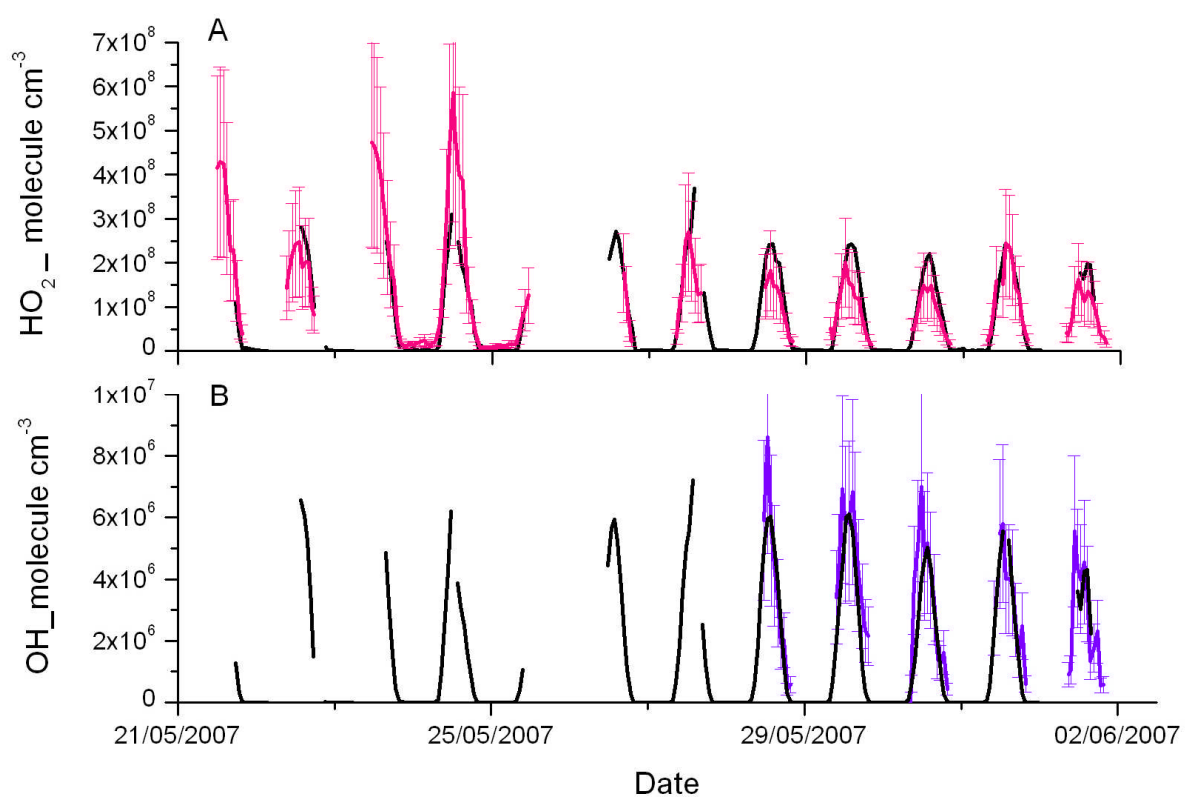

Fig. 4. Panel (A): Time-series of measured $\mathrm{HO}_{2}$ in molecule $\mathrm{cm}^{-3}$ (pink line) with the $2 \sigma$ standard deviation shown and MCM calculated $\left[\mathrm{HO}_{2}\right]$ (base-case scenario, see text for details) (black line). Panel (B): Time-series of measured $\mathrm{OH}$ in molecule $\mathrm{cm}^{-3}$ (purple line) with the $2 \sigma$ standard deviation shown, and MCM [OH] calculated (base-case scenario, see text for details) (black line). All data represent a $1 \mathrm{~h}$ average.

maximum of $\sim 6 \times 10^{8}$ molecule $\mathrm{cm}^{-3}(\sim 24.5 \mathrm{pptv})$ recorded on 24 May (Fig. 3c); [ $\left.\mathrm{NO}_{\mathrm{x}}\right]$ were elevated on this day and may indicate a local pollution source. MCM model estimates of $\left[\mathrm{HO}_{2}\right]$ over this period are also elevated relative to model estimates for later in the campaign (Fig. 4a), although peak MCM modelled $\left[\mathrm{HO}_{2}\right]$ from this period is only $\sim 3 \times 10^{8}$ molecule $\mathrm{cm}^{-3}$, suggesting either a missing source of $\mathrm{HO}_{2}$, or an over-estimation of the $\mathrm{HO}_{2}$ sinks in the model; the modelled $\left[\mathrm{HO}_{2}\right]$ estimates are $\sim 39 \%$ lower than those measured during this phase (falling outside the $1 \sigma$ measurement uncertainty). The daily variability observed in $\left[\mathrm{HO}_{2}\right]$ during this period is also not captured by the model; on 22 May, measured $\left[\mathrm{HO}_{2}\right]$ was significantly lower at $\sim 3 \times 10^{8}$ molecule $\mathrm{cm}^{-3}$, but this drop in $\left[\mathrm{HO}_{2}\right]$ was not reflected in the model. The lack of variability in the modelled $\mathrm{HO}_{2}$ may be due, in part, to the use of a constant average diurnal cycle for $\mathrm{IO}$ and $\mathrm{BrO}$, constant heterogeneous losses and/or constant $[\mathrm{HCHO}]$. Sensitivity analyses of $\left[\mathrm{HO}_{2}\right]$ to each of these modelled parameters have been performed and are presented in Sect. 3.4.

After 26 May the peak measured $\left[\mathrm{HO}_{2}\right]$ were lower $\sim 2-$ $4 \times 10^{8}$ molecule $\mathrm{cm}^{-3}$, and are mirrored by the model. The model is in much better agreement with $\left[\mathrm{HO}_{2}\right]$ measurements during this phase, overestimating $\left[\mathrm{HO}_{2}\right]$ by $16 \%$ on average; this is within the $1 \sigma$ measurement uncertainty of $20 \%$.

$\mathrm{OH}$ measurements were also made during the second measurement period (Fig. 3c). Peak concentrations of $6-9 \times 10^{6}$ molecule $\mathrm{cm}^{-3}$ were recorded; the midday $[\mathrm{OH}]$ gradually decreasing over the 5 days. The model under-predicted $[\mathrm{OH}]$ on average by $18 \%$, although again this is within the $1 \sigma$ measurement uncertainty.

\subsection{Nighttime measured and modelled $\mathrm{HO}_{2}$}

Low concentrations $(\sim 0.6 \mathrm{pptv})$ of $\mathrm{HO}_{2}$ were measured on two nights (24 and 25 May); due to the instrumental difficulties, outlined in Sect. 2.1 no nightime $\mathrm{OH}$ measurements were made. Model estimates of nighttime $\mathrm{HO}_{2}$ significantly under-predict the observations, however (Fig. 5). As reported by Read et al. (2008) a daily $\mathrm{O}_{3}$ destruction cycle is observable at the CVAO, with the majority of this loss due to photolysis of $\mathrm{O}_{3}$ and subsequent reaction of $\mathrm{O}\left({ }^{1} \mathrm{D}\right)$ with $\mathrm{H}_{2} \mathrm{O}$ vapour and via catalytic cycles involving $\mathrm{IO}$ and $\mathrm{BrO}$. The $\mathrm{O}_{3}$ concentration is replenished during the night by entrainment of air from the free tropopshere that is richer in $\mathrm{O}_{3}$, followed by advection to the site (Read et al., 2008). The $\mathrm{HO}_{2}$ concentration was observed to decrease to a minimum at $\sim 21: 30$ and then slowly increase throughout the remainder of the night, analogous to the observed nighttime $\mathrm{O}_{3}$ profile, suggesting that the entrained air during the night is providing a source of radicals.

The nighttime generation of $\mathrm{OH}$ and $\mathrm{HO}_{2}$ in the $\mathrm{MCM}$ box model is from reactions of $\mathrm{O}_{3}$ with alkenes, specifically propene $(\sim 72 \%)$ and isoprene and its oxidation products $(\sim 25 \%)$. The reaction of $\mathrm{NO}_{3}$ with alkenes is not a significant source of $\mathrm{HO}_{2}$, unlike Mace Head (Salisbury et al., 2001). The $\mathrm{OH}$ generated from $\mathrm{O}_{3}+$ alkene reactions reacts with acetaldehyde and methane, leading to the formation of 


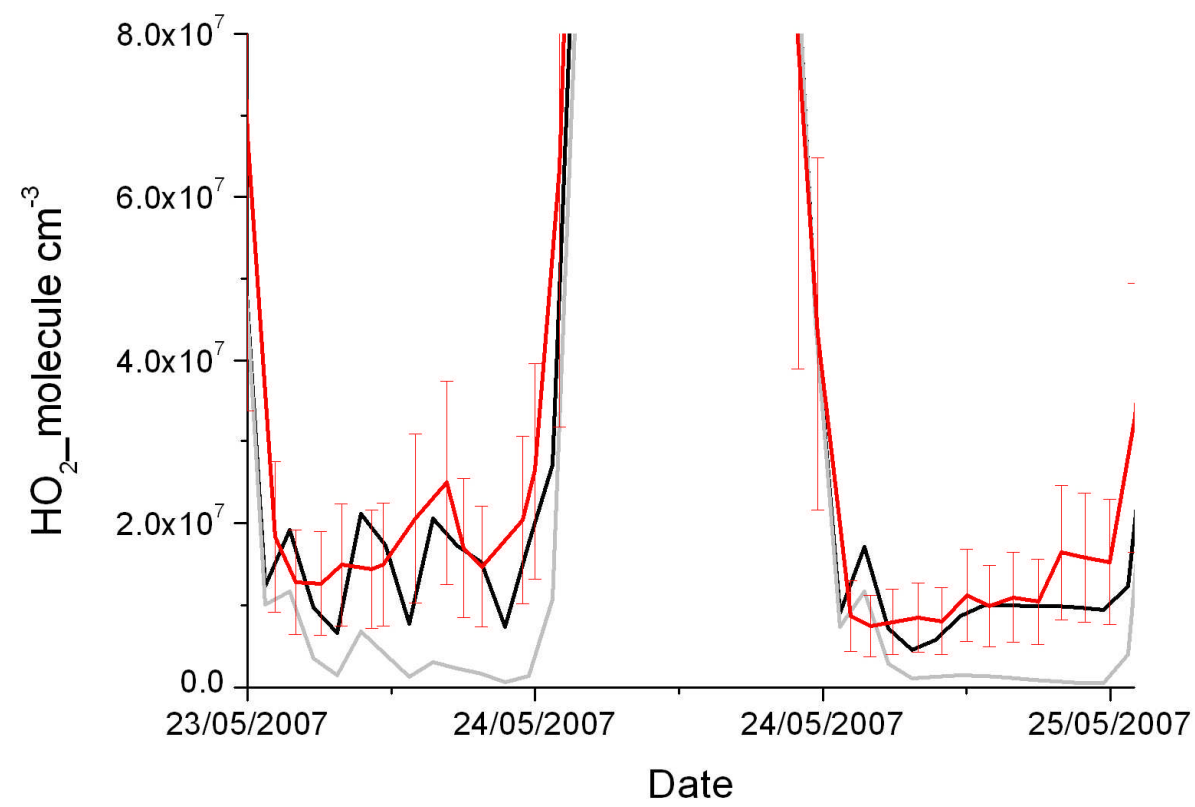

Fig. 5. Time-series of nightime $\left[\mathrm{HO}_{2}\right]$ measured on two consecutive nights. The red line represents the measured $\mathrm{HO}_{2}$, with the $2 \sigma$ standard deviation shown. The grey and black lines represent modelled $\left[\mathrm{HO}_{2}\right]$ when the model is left unconstrained to PAN and when [PAN] is held at 100 pptv respectively.

peroxy radicals, which in turn, through self reaction or reaction with $\mathrm{NO}$ generate $\mathrm{HO}_{2}$. Alternatively, $\mathrm{OH}$ reacts with $\mathrm{CO}$, generating $\mathrm{HO}_{2}$ directly. The $\mathrm{OH}$ and $\mathrm{HO}_{2}$ radicals are strongly coupled at night with $\sim 37 \%$ of $\mathrm{OH}$ formed from the $\mathrm{O}_{3}+\mathrm{HO}_{2}$ reaction. The model underestimation of $\mathrm{HO}_{2}$ at night may derive from an unmeasured alkene, possibly one that is biogenic in origin. Phytoplankton in oceans are known to produce a large suite of VOCs (Moore et al., 1994; Shaw et al., 2003). It is likely, however, that this source would also be present in the daytime, and so would have to be included as an $\mathrm{OH}$ sink.

The entrainment of peroxyacetyl nitrate (PAN) may also act as a nighttime (as well as daytime) source of radicals. In the modelling presented thus far, PAN is unconstrained in the model, and the modelled concentration peaks at $\sim 100 \mathrm{pptv}$ at $\sim 15: 00$, corresponding to the peak in $\mathrm{NO}_{2}$ and then decreases to $\sim 10$ pptv during the night. The thermal decomposition lifetime of PAN is just $20 \mathrm{~min}$ at $300 \mathrm{~K}$ (Bridier et al., 1991), and entrainment of air from the cooler free troposphere (where the PAN lifetime will be much longer) could lead to the rapid decomposition of the molecule, leading to an additional source of radicals. To test this hypothesis, the PAN concentration was constrained in the model to a constant 100 pptv (during both the day and night). Running the model with constrained PAN improves the modelled to measured $\mathrm{HO}_{2}$ throughout the day and night (Fig. 5). Jacobi et al. (1999) have reported PAN concentrations measured during a cruise of the R/V Polarstern from Cape Town (South Africa) to Bremerhaven (Gemany) in May/June 1998.
Whilst cruising a maximum of $500 \mathrm{~km}$ west of the African coast, corresponding to $20^{\circ} \mathrm{W}-15^{\circ} \mathrm{E},(\mathrm{CVAO}$ is $\sim 500 \mathrm{~km}$ west of the coast) PAN concentrations north of $10^{\circ} \mathrm{N}$ (CVAO is at $16^{\circ} 51^{\prime} 49$ ) only dropped below 100 pptv on two days. In contrast to these findings, Gallagher et al. (1990) found that between $7^{\circ} \mathrm{N}-64^{\circ} \mathrm{N}$ and $20^{\circ} \mathrm{W}-50^{\circ} \mathrm{W}$ in late summer that PAN concentrations in the north Atlantic ranged from $<1$ pptv-40 pptv. Similarly, Muller and Rudolph (1992) did not measure PAN above the LOD of $10 \mathrm{pptv}$ in the tropics $\left(30^{\circ} \mathrm{N}-30^{\circ} \mathrm{S}\right)$ when crusising at $30^{\circ} \mathrm{W}$. The proximity of the measurement sites to the African coast seems to strongly influence the PAN content of the sampled air-masses (Jacobi et al., 1999). Trajectory analysis from the RHaMBLe campaign indicated that for 21-25 May (during which time the nighttime measurements of $\mathrm{HO}_{2}$ were made) the air-masses intercepted at the CVAO were influenced by the US continent. In such air-masses the PAN content may have been enhanced, and, therefore, could act as an important radical source. Measurements of PAN at the site are necessary to confirm this hypothesis.

\subsection{Rate of production and destruction analysis}

Figure 6 shows the instantaneous rates of production (ROPA) and rates of destruction analyses (RODA) for $\mathrm{OH}$ and $\mathrm{HO}_{2}$ at solar noon (averaged for the period 12:00-13:00 LT - local time) as determined by the MCM. The ROPA and RODA are averaged over all days for which there are respective measurements of $\mathrm{OH}$ and $\mathrm{HO}_{2}$. Figure 7 shows the diurnal 

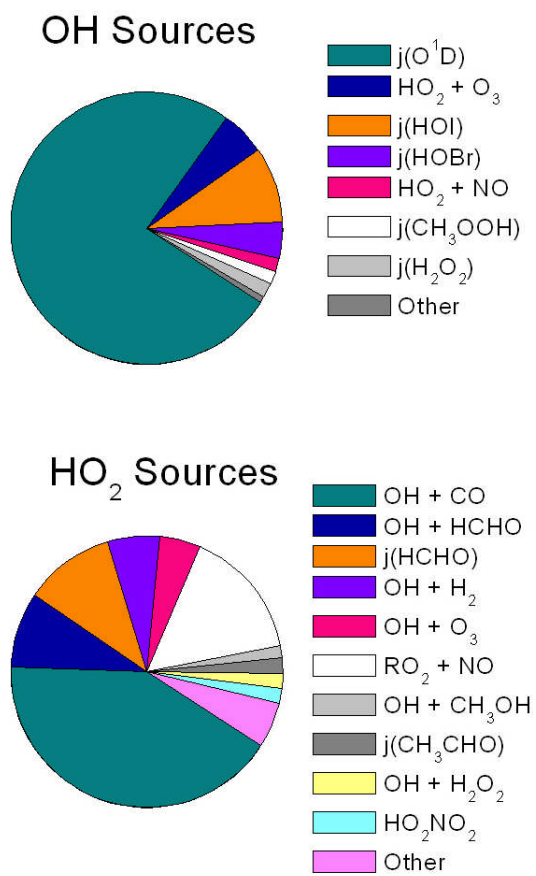
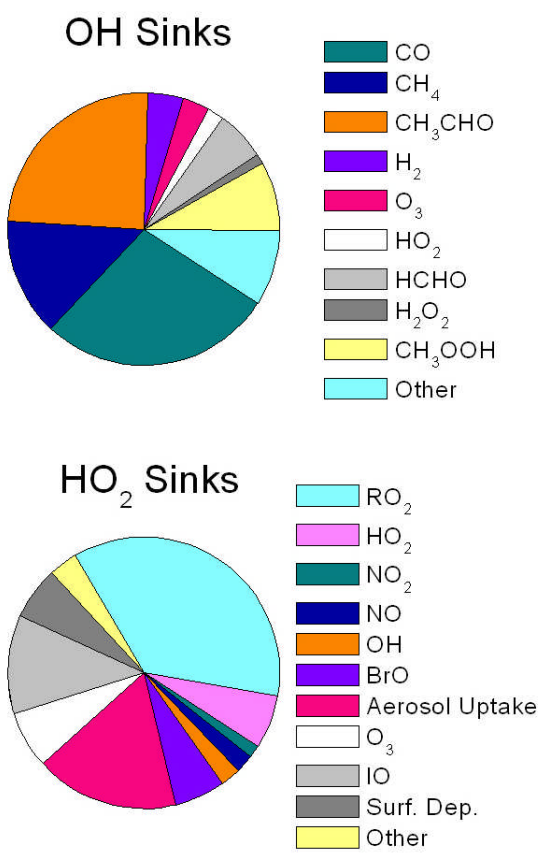

Fig. 6. Pie-charts showing the MCM (base-case scenario, see text for details) average diurnal modelled $\mathrm{OH}_{\text {and }} \mathrm{HO}_{2}$ sources and sinks between 12:00-13:00.

variation of the MCM calculated rates of production and destuction of $\mathrm{OH}$ and $\mathrm{HO}_{2}$ for different chemical processes, again averaged over the days when there are radical measurements. It should be noted that several of the pathways serve to inter-convert $\mathrm{OH}$ to $\mathrm{HO}_{2}$, or vice versa, and so, overall, do not lead to an increase or decrease in the total $\mathrm{HO}_{\mathrm{x}}$.

The photolysis of $\mathrm{O}_{3}$ and subsequent reaction with $\mathrm{H}_{2} \mathrm{O}$ vapour represents the dominant $\mathrm{OH}$ source, accounting for $\sim 76 \%$ of its production at solar noon. The photolysis of $\mathrm{H}_{2} \mathrm{O}_{2}$ and $\mathrm{CH}_{3} \mathrm{OOH}$ are much smaller $\mathrm{OH}$ sources $(\sim 3 \%$ combined); at steady state these peroxides reach levels of $\sim 500$ pptv and $\sim 1$ ppbv respectively in the model, similar in magnitude to observations of peroxides at Cape Grim (Ayers et al., 1996; Monks et al., 1998) and also in the Cape Verde region during the ALBATROSS cruise (Weller et al., 2000). The recycling of $\mathrm{HO}_{2}$ to $\mathrm{OH}$, via reaction with $\mathrm{NO}$ and $\mathrm{O}_{3}$, also act as small additional $\mathrm{OH}$ sources. The hypohalous acids, $\mathrm{HOI}$ and $\mathrm{HOBr}$, which are generated by the reaction of $\mathrm{HO}_{2}$ with IO and BrO respectively (Fig. 1), may be photolysed to $\mathrm{OH}$ or taken up on aerosol surfaces. An uptake coefficient for HOI and HOBr loss onto aerosols of $\gamma_{\mathrm{HOX}}=0.061$ was assumed, consistent with experimental data (Mossinger and Cox, 2001). Under this scenario, the photolysis of HOI and $\mathrm{HOBr}$ contributes $\sim 13 \%$ to the instantaneous $\mathrm{OH}$ formation. There is some uncertainty in the $\gamma_{\text {HOX }}$ assumed, with some studies speculating that it may be an order of magnitude higher in the MBL (Abbatt and Waschewsky, 1998; Wachsmuth et al., 2002). The sensitivity of the modelled $[\mathrm{OH}]$ to this parameter is investigated in Sect. 3.4.2.
The reactions of $\mathrm{OH}$ with $\mathrm{CO}$ and acetaldehyde are the major OH losses ( $\sim 28 \%$ and $\sim 25 \%$ respectively). The source of acetaldehyde at remote marine locations, such as Cape Verde, has not been determined conclusively and remains subject to debate. Acetaldehyde is formed by the oxidation of primary hydrocarbons, it may derive from direct terrestrial emissions or from the photochemical degradation of organic matter in the oceans (Singh et al., 2001 and references therein). Singh et al. (2003) have inferred from aircraft measurements of acetaldehyde that the surface waters of the Pacific are greatly supersaturated with acetaldehyde and may act as a large oceanic source. Read et al. (2010) suggest that an oceanic flux of acetaldehyde is a likely source of the observed acetaldehyde concentrations in the Cape Verde region also. In contrast to acetaldehyde, the other oxygenated VOCs that were measured (acetone and methanol) play only a minor role as an $\mathrm{OH}$ sink (contained within "other" in Fig. 6). Other sinks include reaction with methane, $\mathrm{H}_{2}, \mathrm{O}_{3}, \mathrm{HO}_{2}$, $\mathrm{HCHO}$ and peroxides. Reaction of $\mathrm{OH}$ with $\mathrm{NO}_{2}, \mathrm{C}_{2}-\mathrm{C}_{5}$ hydrocarbons (NMHC) and MCM calculated chemical intermediates from $\mathrm{OH}$ oxidation of NMHC (oxygenated VOCs and organo-nitrates) all account for a small fraction of the $\mathrm{OH}$ loss, and are contained within the "other" segment also.

$\mathrm{HO}_{2}$ sources are dominated by the reaction of $\mathrm{OH}$ with $\mathrm{CO}(\sim 41 \%)$ and, to a smaller extent, $\mathrm{CH}_{3} \mathrm{O}$ with $\mathrm{O}_{2} \quad(\sim 16 \%)$; the source of $\mathrm{CH}_{3} \mathrm{O}$ is the reaction of $\mathrm{CH}_{3} \mathrm{O}_{2}$ with NO. The presence of a small quantity of $\mathrm{NO}(\sim 1.5 \mathrm{pptv})$ at the site serves to slightly enhance $\mathrm{HO}_{2}$ levels overall, because although $\mathrm{HO}_{2}+\mathrm{NO}$ removes $\mathrm{HO}_{2}$ 

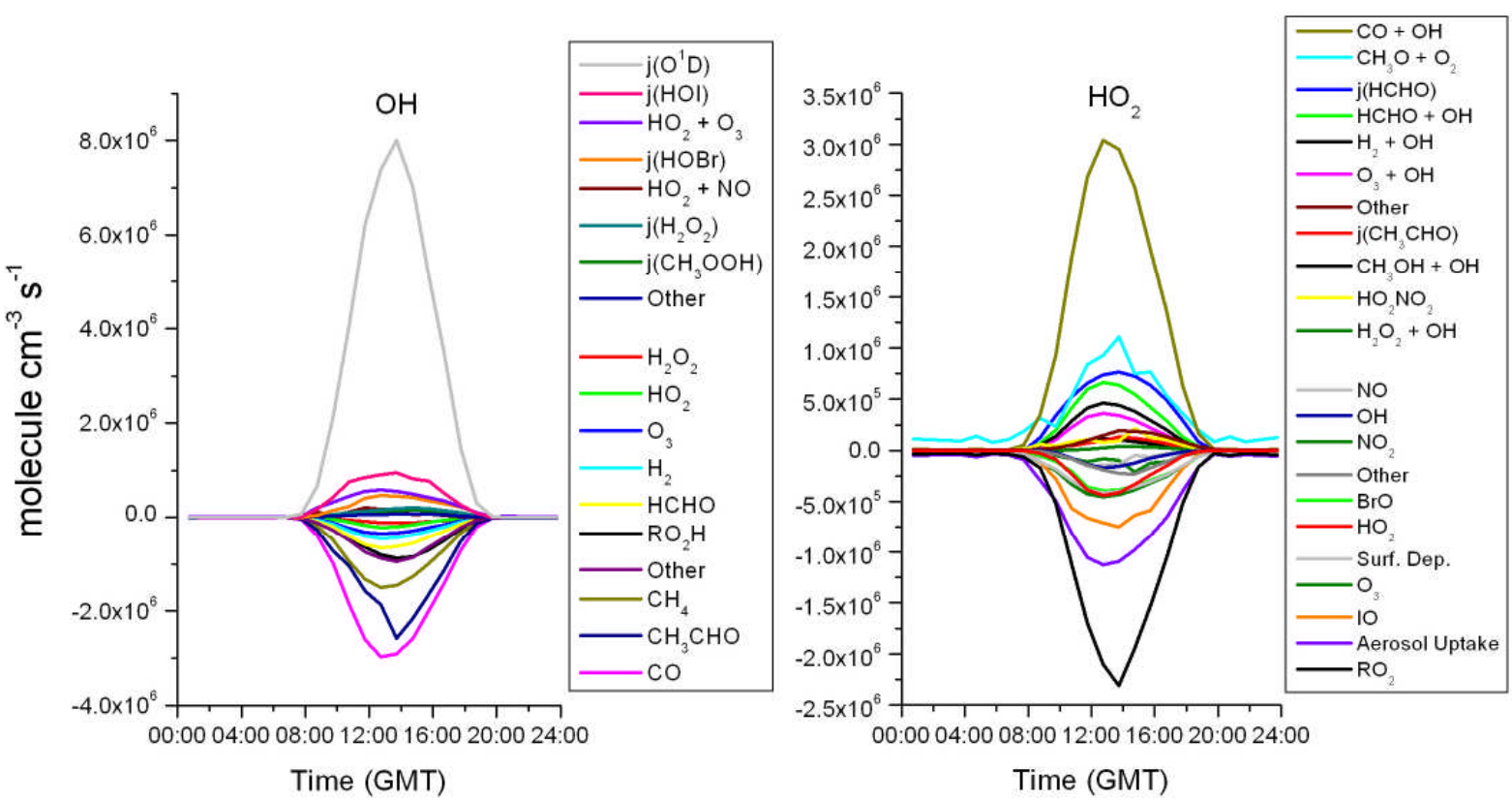

Fig. 7. Left: Diurnal variation of the rate of $\mathrm{OH}$ production and loss calculated using the $\mathrm{MCM}$ Right: Diurnal variation of the rate of $\mathrm{HO}_{2}$ production and loss taken from the MCM (base case, see text for details).

(Reaction R10), this is offset at these low levels of [NO] by a larger overall rate of $\mathrm{RO}_{2}+\mathrm{NO} \rightarrow \mathrm{RO}+\mathrm{NO}_{2}$ (followed by rapid $\mathrm{HO}_{2}$ production from $\mathrm{RO}+\mathrm{O}_{2}$ ) leading to a net production of $\mathrm{HO}_{2}$ (Reactions R11 and R14) (Poppe, 1999). If NO concentrations were to increase further, $\left[\mathrm{RO}_{2}\right]$ would decrease (Fleming et al., 2006) and $\mathrm{HO}_{2}+\mathrm{NO}$ (Reaction R10) would begin to dominate over $\mathrm{RO}_{2}+\mathrm{NO}$ (Reaction R11) (as $k_{10}=8.9 \times 10^{-12}$ molecule ${ }^{-1} \mathrm{~cm}^{3} \mathrm{~s}^{-1}$ is $>k_{11}=7.7 \times 10^{-12}$ molecule ${ }^{-1} \mathrm{~cm}^{3} \mathrm{~s}^{-1}$ (IUPAC, 2006)). Under this regime, reactions involving $\mathrm{NO}$ would act as an $\mathrm{HO}_{2}$ sink rather than a source. The sensitivity of the radicals to $\mathrm{NO}_{\mathrm{x}}$ levels is further discussed in the subsequent section (Sect. 3.4.2).

$\mathrm{RO}+\mathrm{O}_{2} \rightarrow$ Aldehyde $+\mathrm{HO}_{2}$

The reaction of $\mathrm{HCHO}$ with $\mathrm{OH}$, combined with the photolysis of $\mathrm{HCHO}$, can contribute close to $20 \%$ of the $\mathrm{HO}_{2}$ at solar noon. Other smaller $\mathrm{HO}_{2}$ sources include $\mathrm{OH}+\mathrm{H}_{2}, \mathrm{OH}+\mathrm{O}_{3}$, $\mathrm{CH}_{3} \mathrm{OH}+\mathrm{OH}, j\left(\mathrm{CH}_{3} \mathrm{CHO}\right), \mathrm{OH}+\mathrm{H}_{2} \mathrm{O}_{2}$ and $\mathrm{HO}_{2} \mathrm{NO}_{2}$ thermolysis.

The reaction of $\mathrm{HO}_{2}$ with $\mathrm{IO}$ and $\mathrm{BrO}$ accounts for a combined, instantaneous, $\mathrm{HO}_{2}$ loss of $\sim 19 \%$, despite these species only being present at $\sim 1.4 \mathrm{pptv}$ and $\sim 2.5 \mathrm{pptv}$ (peak daytime levels) respectively. The major $\mathrm{HO}_{2}$ sink is the reaction with $\mathrm{RO}_{2}\left(\mathrm{R}=\mathrm{CH}_{3}-\mathrm{C}_{5} \mathrm{H}_{11}\right)$ (Reaction R15), typical of low $\mathrm{NO}_{\mathrm{x}}$ environments (Carpenter et al., 1997; Penkett et al., 1997), which together with the self reaction (Reaction R16) accounts for over $40 \%$ of the total $\mathrm{HO}_{2}$ loss.

$\mathrm{HO}_{2}+\mathrm{RO}_{2} \rightarrow \mathrm{RO}_{2} \mathrm{H}+\mathrm{O}_{2}$
$\mathrm{HO}_{2}+\mathrm{HO}_{2} \rightarrow \mathrm{H}_{2} \mathrm{O}_{2}+\mathrm{O}_{2}$

Heterogeneous loss to aerosol and surface deposition accounts for $\sim 23 \%$ of the $\mathrm{HO}_{2}$ loss at noon-time.

Over a $24 \mathrm{~h}$ period, the relative contribution of the $\mathrm{HO}_{\mathrm{x}}$ sources and sinks remains fairly consistent, as shown in Fig. 7. There is some deviation from the trend discussed above, and displayed in Fig. 6, for example the reaction of $\mathrm{OH}$ with $\mathrm{CH}_{3} \mathrm{CHO}$ and reactions involving $\mathrm{HO}_{2} \mathrm{NO}_{2}$ peak in the afternoon, reflecting the afternoon peak in the concentrations of $\mathrm{CH}_{3} \mathrm{CHO}$ and $\mathrm{NO}_{2}$ as measured at the site. In the morning and evening (when the concentration of $\mathrm{HO}_{2}$ is low) the reaction of $\mathrm{HO}_{2}$ with $\mathrm{O}_{3}$ dominates over the $\mathrm{HO}_{2}$ self reaction promoting radical recycling rather than radical termination. The reaction of $\mathrm{HO}_{2}$ with $\mathrm{IO}$ and $\mathrm{BrO}$ exhibits a broad diurnal cycle that reflects light intensity.

\subsection{Sensitivity analysis of modelled $\mathrm{OH}$ and $\mathrm{HO}_{2}$ concentrations}

The mean diurnal profiles of the observed and modelled $[\mathrm{OH}]$ and $\left[\mathrm{HO}_{2}\right]$ has been calculated (Fig. 8) over all days for which there were respective measurements of $\mathrm{OH}$ and $\mathrm{HO}_{2}$. Owing to instrumental difficulties outlined in Sect. 2 only daytime $\mathrm{OH}$ data are available. In general good agreement between the modelled and measured $[\mathrm{OH}]$ profile is achieved (Fig. 8a and C). The model under-predicts $[\mathrm{OH}]$ in the mid-morning, and during the very late afternoon and evening, although for the latter, $\mathrm{OH}$ levels are close to the LOD of the instrument. $\mathrm{HO}_{2}$ was measured on 11 days and 

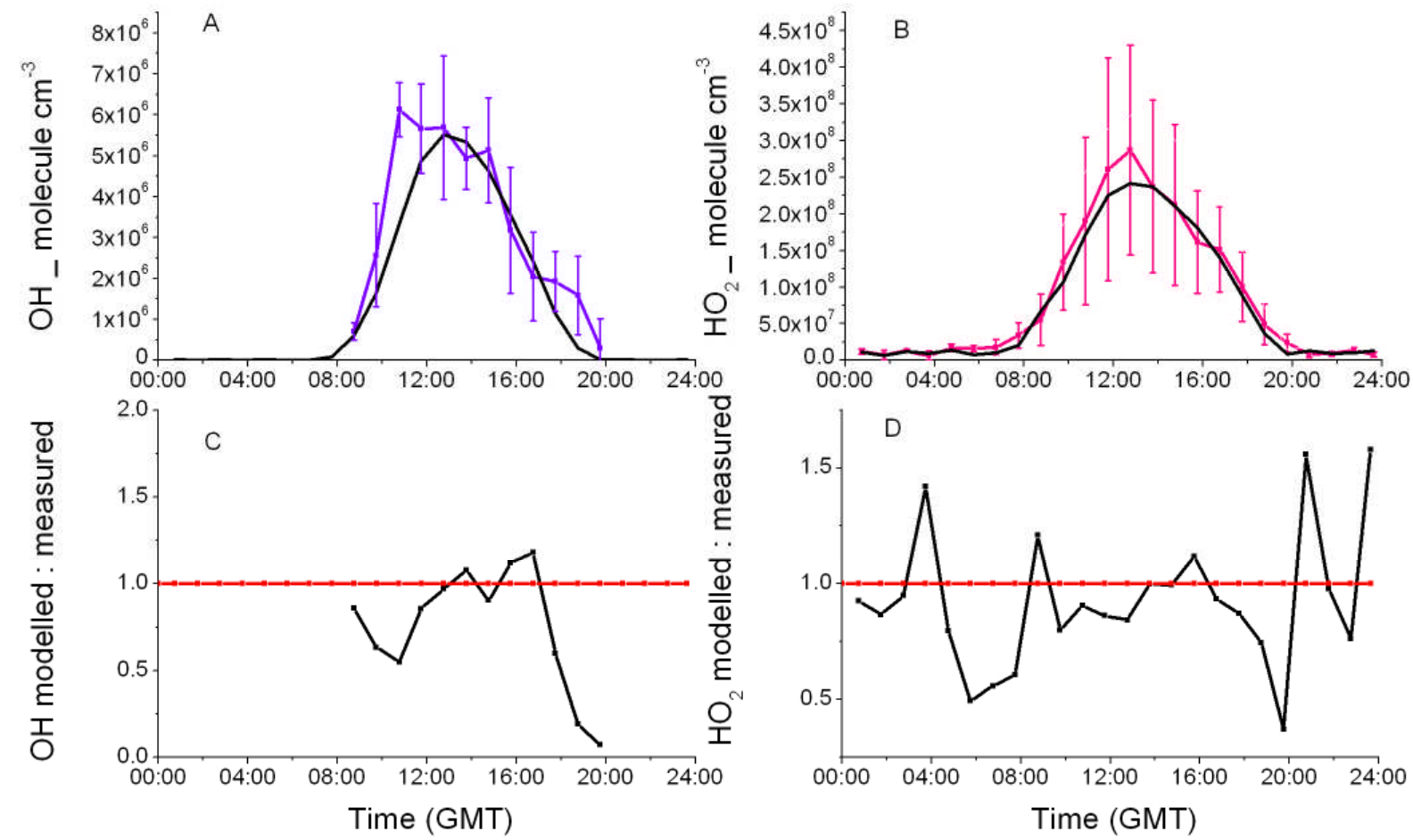

Fig. 8. Panel (A): Average diurnal $[\mathrm{OH}]$ calculated for the 5 days of measurements (data on an hourly time-scale); the error bars represent the standard deviation of the data that were averaged (purple points and line). The modelled average diurnal (averaged over the 5 days of $\mathrm{OH}$ measurements) is also shown ( $\mathrm{MCM}=$ grey line). Panel $(\mathbf{B})$ : Average diurnal $\left[\mathrm{HO}_{2}\right]$ calculated for the 11 days of measurements (data on an hourly time-scale); the error bars represent the standard deviation of the data that was averaged (pink points and line). The modelled average diurnal (averaged over the 11 days of $\mathrm{HO}_{2}$ measurements) is also shown (MCM= black line). Panel (C): Solid line, with black squares represents the $(\mathrm{OH} \mathrm{MCM}$ modelled $) /(\mathrm{OH}$ measured $)$ ratio averaged for $1 \mathrm{~h}$ over $24 \mathrm{~h}$. Panel (D): Solid line represents the $\left(\mathrm{HO}_{2} \mathrm{MCM}\right.$ modelled $) /\left(\mathrm{HO}_{2}\right.$ measured ratio) averaged for $1 \mathrm{~h}$, for a $24 \mathrm{~h}$ period. Red line in panels $\mathrm{C}$ and $\mathrm{D}$ represents modelled : measured ratio of 1 .

2 nights, enabling a complete $24 \mathrm{~h}$ average diurnal profile to be built up. Excellent agreement between observed and modelled $\left[\mathrm{HO}_{2}\right]$ is achieved (Fig. $8 \mathrm{~b}$ and d) during the daytime; during the nightime the $\left[\mathrm{HO}_{2}\right]$ is replicated when the model is constrained to a constant [PAN] of $100 \mathrm{pptv}$ (Sect. 3.2). As highlighted in Figs. 3 and 4 (and discussed in Sect. 3.1), significant variability was observed in the measured daily peak $\left[\mathrm{HO}_{2}\right]$, certainly when different air-masses were intercepted; this variability was not replicated in model simulations to the same extent and so the agreement between the modelled and measured $\left[\mathrm{HO}_{2}\right]$ in Fig. 8 may be slightly fortuitous. It should be noted, however, that owing to the more extensive data coverage during the latter half of the measurement period, when the agreement between the daily modelled and observed $\left[\mathrm{HO}_{2}\right]$ was at its best (Fig. 4), the diurnal profiles will be more heavily weighted to this phase. Several key modelled parameters that control the production and loss of $\mathrm{HO}_{2}$ have been identified in Sect. 3.3, a number of which were either held at constant values ([HCHO] and heterogeneous chemistry) or used a constant diurnal profile ([XO]) within the model. A number of model scenarios in which these parameters are varied have been run to determine the impact of these on the modelled $\left[\mathrm{HO}_{2}\right]$ (and $[\mathrm{OH}])$ and to assess whether varying these parameters could account for the daily variability in the observations. Table 2 lists the changes made and their impact on modelled $\left[\mathrm{HO}_{2}\right]$, and Fig. 9 shows the impact on the diurnal variation of the modelled-to-measured ratio of $\left[\mathrm{HO}_{2}\right]$. The uptake coefficient of the hypohalous acids has also been varied, in accord with reported literature values, to determine the sensitivity of $[\mathrm{OH}]$ (and $\left[\mathrm{HO}_{2}\right]$ ) to this:

\subsubsection{HCHO}

As discussed in Sect. 3.3, the reaction of $\mathrm{OH}$ with $\mathrm{HCHO}$ and $\mathrm{HCHO}$ photolysis are sources of $\mathrm{HO}_{2}$. The model thus far has been constrained to a constant $\mathrm{HCHO}$ concentration of $328 \mathrm{pptv}$, which is the mean HCHO concentration observed during May 2007, as measured using the LP-DOAS during its 8 month deployment at the observatory. It should be noted, however, that throughout the 8 months [HCHO] were variable, dropping below the LOD of the LP-DOAS $(\sim 200$ pptv) at times and elevated in polluted air-masses. Recent analysis of the HCHO data during the RHaMBLe measurement intensive has highlighted that $[\mathrm{HCHO}]$ were 
Table 2. List of parameters that have been varied to optimise the $\mathrm{HO}_{2}$ modelled to measured agreement. The daytime \% change was averaged from 08:44-19:44; the nighttime \% change was averaged from 19:44-08:44.

\begin{tabular}{|c|c|c|c|c|}
\hline Model Parameter & Parameter Change & $\begin{array}{l}\text { Av. \% Change } \\
\text { in } \mathrm{HO}_{2} \text { (day) }\end{array}$ & $\begin{array}{l}\text { Av. \% Change } \\
\text { in } \mathrm{HO}_{2} \text { (night) }\end{array}$ & $\begin{array}{r}\text { Av. \% Change } \\
\text { in } \mathrm{OH} \text { (day) }\end{array}$ \\
\hline $\mathrm{HCHO}$ & $328 \mathrm{pptv} \rightarrow 100 \mathrm{pptv}$ & -8 & 0 & +2 \\
\hline $\mathrm{HCHO}$ & $328 \mathrm{pptv} \rightarrow 2000 \mathrm{pptv}$ & +60 & +1 & -9 \\
\hline Halogen chemistry & XO chemistry switched off & +12 & +2 & -12 \\
\hline $\begin{array}{l}\text { Halogen chemistry (modified } \\
{\left[\mathrm{NO}_{\mathrm{X}}\right]}\end{array}$ & $\begin{array}{l}\mathrm{XO} \text { chemistry switched off } \\
\&\left[\mathrm{NO}_{\mathrm{X}}\right] \rightarrow \text { doubled }\end{array}$ & +18 & 0 & -9 \\
\hline Hypohalous acid chemistry & $\gamma_{\mathrm{HOX}}=0.061 \rightarrow 0.61$ & -2 & 0 & -4 \\
\hline Aerosol uptake & Included $\rightarrow$ Not included & +29 & +59 & +7 \\
\hline Surface deposition & Included $\rightarrow$ Not included & +9 & +16 & +2 \\
\hline $\begin{array}{l}\text { Heterogeneous losses } \\
\& \text { halogen chemistry }\end{array}$ & $\begin{array}{l}\text { No heterogeneous loss, } \\
\text { no IO chemistry, }[\mathrm{BrO}] \times 1.4\end{array}$ & +52 & +104 & -3 \\
\hline
\end{tabular}

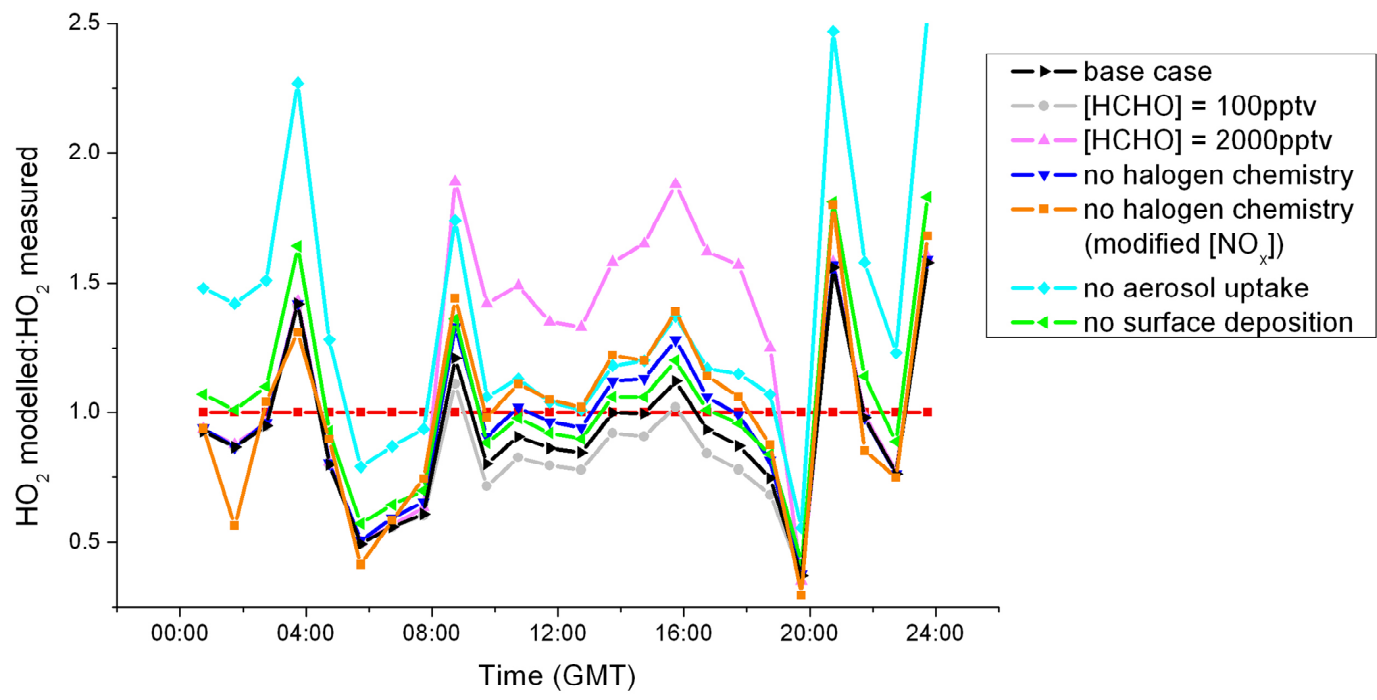

Fig. 9. $\left(\mathrm{HO}_{2} \mathrm{MCM}\right.$ modelled)/( $\mathrm{HO}_{2}$ measured) ratio for a number of different model scenarios. Black line = base case scenario (with $[\mathrm{PAN}]=100 \mathrm{pptv}$ ), all other scenarios are based on this model with the specified (see legend) parameters adjusted. Red line represents an $\left(\mathrm{HO}_{2} \mathrm{MCM}\right.$ modelled $) /\left(\mathrm{HO}_{2}\right.$ measured $)$ of 1 . See text and Table 2 for further details.

extremely elevated ( $\sim 2 \mathrm{ppbv}$ ) on the 23 and 24 May (and also on the 27 and 28 May, although $\mathrm{HO}_{2}$ data is limited during this second period due to power cuts). These large excursions from the more typical [HCHO] used in the model could account for the model's failure to replicate the elevated $\left[\mathrm{HO}_{2}\right]$ observed at the beginning of the measurement period (Fig. 4).

Two model runs whereby [HCHO] was reduced to 100 pptv (Fig. 9, grey line) and increased to 2 ppbv (Fig. 9, pink line) have been performed. Reducing the HCHO concentration from $328 \mathrm{pptv}$ to $100 \mathrm{pptv}$ decreases $\left[\mathrm{HO}_{2}\right]$ by $\sim 8 \%$ during the daytime, but does not effect the nighttime levels of $\mathrm{HO}_{2}$ (Table 2); at [HCHO] of $2 \mathrm{ppbv},\left[\mathrm{HO}_{2}\right]$ increases by $\sim 60 \%$ on average from the base-case scenario. Approximately a $140 \%$ increase in the base-case model is required to match the elevated $\left[\mathrm{HO}_{2}\right]$ observed at the beginning of the measurement period. This remaining discrepancy may indicate that the model is missing other additional $\mathrm{HO}_{2}$ sources at this time or potentially that the $\mathrm{HO}_{2}$ sinks are over-estimated by the model at this time (see Sect. 3.4.2 and 3.4.3). During the ALBATROSS cruise, up to $1 \mathrm{ppbv}$ of $\mathrm{HCHO}$ was observed in the tropical mid-Atlantic (Brauers et al., 2001) and 750 pptv was recorded in the Cape Verde region (Weller et al., 2000). At Cape Grim, Tasmania during the SOAPEX-2 campaign, during clean conditions, [HCHO] was measured around noon from $217-352$ pptv (with $50 \%$ 
error) (Sommariva et al., 2004). The source of the high [HCHO] observed during RHaMBLe may be caused by longrange transport of polluted air from America; this will be further investigated in future publications (Mahajan et al., 2010).

\subsubsection{Halogen chemistry}

The inclusion of a halogen scheme has been shown to improve the $\mathrm{HO}_{2}$ modelled to measured agreement at a number of marine locations (Bloss et al., 2005b; Smith et al., 2006; Sommariva et al., 2006; Kanaya et al., 2007). Sommariva et al. (2006) report that combined, IO and $\mathrm{BrO}$ accounted for $\sim 30 \%$ of the $\mathrm{HO}_{2}$ loss term during the NAMBLEX campaign at $[\mathrm{IO}]=4$ pptv and $[\mathrm{BrO}]=6.5$ pptv. Switching the halogen chemistry off in the Cape Verde model serves to increase $\left[\mathrm{HO}_{2}\right]$ by $\sim 12 \%$ during the daytime and $\sim 2 \%$ during the night. $[\mathrm{OH}]$ decreases by $\sim 12 \%$. Sommariva et al. (2006) found that the modelled to measured $\mathrm{HO}_{2}$ agreement could be improved further during the NAMBLEX campaign by making the assumption that the source of IO was not evenly distributed over the DOAS light-path, rather it was concentrated by the shore close to the $\mathrm{HO}_{2}$ FAGE measurements, and as a consequence $[\mathrm{IO}]$ was $\sim 10$ times higher by the FAGE inlet. There are no macro-algae beds around the Cape Verde islands unlike Mace Head that could be acting as a source of IO and so it is unlikely that there is a hotspot of IO production by the CVAO; this is supported by the good modelled to measured $\mathrm{HO}_{2}$ agreement that exists when it is assumed that the $[\mathrm{IO}]$ is evenly distributed throughout the DOAS lightpath, representative of an oceanic source. If there were some variability in the oceanic emissions from day to day this could account for some of the variability observed in the $\mathrm{HO}_{2}$ concentrations.

As discussed in Sect. 3.3, the overall impact of halogen chemistry on the $\mathrm{OH}$ concentration will be dependent upon the uptake coefficient assumed for the hypohalous acid species. To investigate the sensitivity of $[\mathrm{OH}]$ and $\left[\mathrm{HO}_{2}\right]$ to this parameter, a model run was performed in which $\gamma_{\mathrm{HOX}}$ was increased 10 fold from the base-case run (see Table 2). The $[\mathrm{OH}]$ was found to decrease by $4 \%$ during the day and so under this scenario the impact of halogen oxides upon $[\mathrm{OH}]$ and on the oxidising capacity is reduced, although the photolysis of $\mathrm{HOI}$ and $\mathrm{HOBr}$ is still acting as a significant $\mathrm{OH}$ source. The $\left[\mathrm{HO}_{2}\right]$ during the daytime is also reduced by $2 \%$ under this scenario as a consequence of the reduction in the rate of reaction of $\mathrm{OH}$ with $\mathrm{CO}$.

The presence of halogen oxides not only serves to modify the $\mathrm{HO}_{\mathrm{x}}$ chemistry, but also the $\mathrm{NO}_{\mathrm{x}}$ chemistry by accelerating $\mathrm{NO}_{\mathrm{x}}$ oxidation through Reactions (R7) and (R17). Thus far, the impact of $\mathrm{IO}$ and $\mathrm{BrO}$ on $\mathrm{NO}_{\mathrm{x}}$ chemistry has not been considered, yet any change in the $\mathrm{NO}: \mathrm{NO}_{2}$ ratio can perturb the $\mathrm{OH}: \mathrm{HO}_{2}$ ratio by changing the rate of Reactions (R10) and (R11).

$\mathrm{XO}+\mathrm{NO}_{2}+\mathrm{M} \rightarrow \mathrm{XONO}_{2}+\mathrm{M}$
Keene et al. (2009) report a reduction in $[\mathrm{OH}]$ in a modelling study when halogen oxide chemistry was included as a consequence in the reduction in the secondary formation of $\mathrm{OH}$ via Reaction R10 (Keene et al., 2009). Modelling studies indicate that $\mathrm{NO}_{\mathrm{x}}$ levels could approximately double in the absence of halogen oxides in environments similar to Cape Verde (Keene et al., 2009). To simulate the overall impact of halogen oxides, taking into account that $\mathrm{NO}_{\mathrm{x}}$ levels may be significantly perturbed due to the presence of halogens, a model run, initialised with no halogens and a factor of two increase in the $\mathrm{NO}_{\mathrm{x}}$ concentration, has been performed. In contrast to Keene et al. (2009), OH concentrations were found to be $9 \%$ larger in the presence of halogen oxides compared to in the absence of halogen oxides (but with double $\left[\mathrm{NO}_{\mathrm{x}}\right]$ ) (Table 2); the perturbation of the $\mathrm{NO}_{\mathrm{x}}$ chemistry by halogen oxides offsets the instantaneous $\mathrm{OH}$ formation via HOI and HOBr photolysis by $\sim 3 \%$. Keene et al. (2009) consider the impact of $\mathrm{BrO}$ and $\mathrm{ClO}$ only; no IO measurements were made. The rate coefficient for reaction of $\mathrm{ClO}$ with $\mathrm{HO}_{2}\left(5 \times 10^{-12}\right.$ molecule ${ }^{-1} \mathrm{~cm}^{3} \mathrm{~s}^{-1}$; IUPAC, 2006) is a factor of two times smaller than the rate coefficient for reaction of $\mathrm{ClO}$ with $\mathrm{NO}\left(1.7 \times 10^{-11}\right.$ molecule $\mathrm{cm}^{-1} \mathrm{~cm}^{3} \mathrm{~s}^{-1}$ IUPAC, 2006). Depending on $\left[\mathrm{HO}_{2}\right]$ and $[\mathrm{NO}]$, the presence of $\mathrm{ClO}$ can effectively lead to a reduction in $[\mathrm{OH}]$, as presented by Keene et al. (2009). Conversely, the rate coefficient for reaction of IO with $\mathrm{HO}_{2}\left(8.4 \times 10^{-11}\right.$ molecule ${ }^{-1} \mathrm{~cm}^{3} \mathrm{~s}^{-1}$; IUPAC, 2006) is larger than the rate coefficient for reaction of IO with NO $\left(1.96 \times 10^{-11}\right.$ molecule $\mathrm{e}^{-1} \mathrm{~cm}^{3} \mathrm{~s}^{-1}$; IUPAC, 2006) and so the presence of $\mathrm{IO}$, in low $\mathrm{NO}_{\mathrm{x}}$ environments, serves to increase $[\mathrm{OH}]$. The absence of IO chemistry in the model used by Keene et al. (2009) could account for the differences in the modelled impacts of halogens on $[\mathrm{OH}]$. The difference between the two model scenerios in which halogen chemistry is switched off and $\mathrm{NO}_{\mathrm{x}}$ chemistry is (a) constrained to observations and (b) is doubled, allows the impact of variable $\left[\mathrm{NO}_{\mathrm{x}}\right]$ upon $[\mathrm{OH}]$ and $\left[\mathrm{HO}_{2}\right]$ to be assessed. On average, modelled $[\mathrm{OH}]$ and $\left[\mathrm{HO}_{2}\right]$ increased by a further $3 \%$ and $6 \%$ respectively via increases in Reactions (R10) and $(\mathrm{R} 11)$ when $\left[\mathrm{NO}_{\mathrm{x}}\right]$ was set to twice the observations. As discussed above, halogen oxides can perturb this chemistry and need to be condsidered alongside $\mathrm{NO}_{\mathrm{x}}$ to predict how potential changes in $\left[\mathrm{NO}_{\mathrm{x}}\right]$ may impact $\left[\mathrm{HO}_{\mathrm{x}}\right]$ in this environment.

\subsubsection{Heterogeneous losses of $\mathrm{HO}_{2}$}

Heterogeneous loss of $\mathrm{HO}_{2}$ acts as a large $\mathrm{HO}_{2}$ sink (Sect. 3.3). If the uptake onto aerosol surfaces is assumed negligible, modelled $\left[\mathrm{HO}_{2}\right]$ increases by $29 \%$ during the daytime and by $59 \%$ at night, leading to a large modelled $\mathrm{HO}_{2}$ over-prediction. A change in the aerosol surface area and/or composition could account for some of the daily variability observed in $\mathrm{HO}_{2}$. Thornton et al. (2008) report that the uptake coefficient for $\mathrm{HO}_{2}$ may vary considerably with changes in aerosol composition. Certainly, if heterogenous 


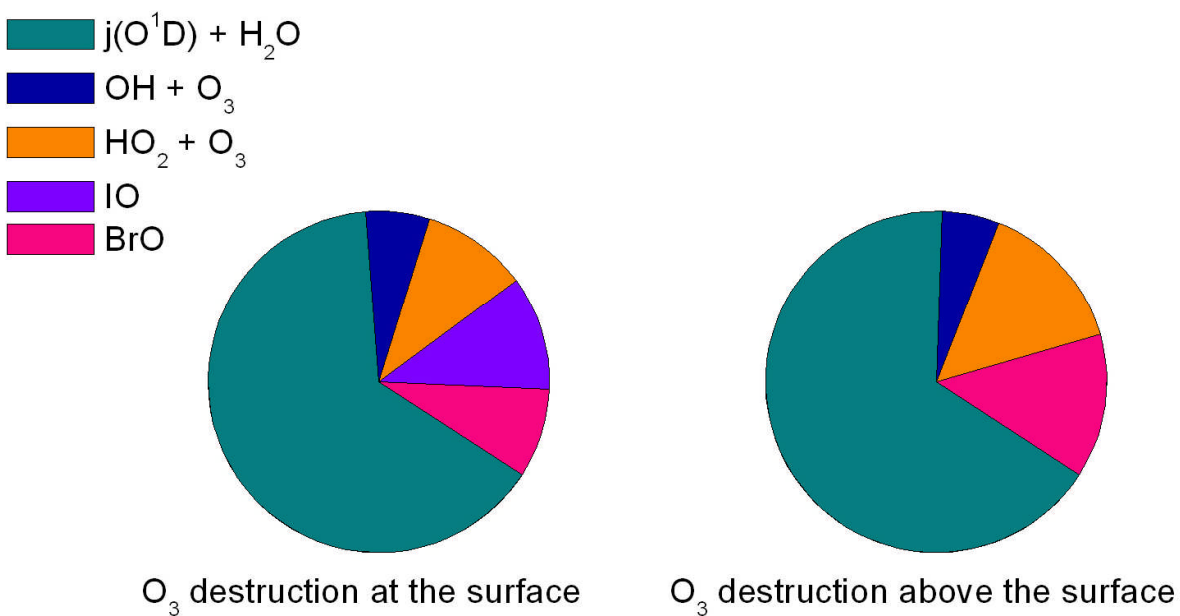

Fig. 10. Pie-charts highlighting the key parameters that cause the daily $\mathrm{O}_{3}$ destruction that is observed at the CVAO both at the surface (left panel) and at the top of the MBL (right panel). Total $\mathrm{O}_{3}$ destruction calculated using $12 \mathrm{~h}$ averaged, daytime, data was $\sim 4$ ppbv at the surface and $\sim 3.5 \mathrm{ppbv}$ at the top of the MBL.

loss processes to aerosol surfaces were lower during the interception of the long-range transported airmass compared with loss processes during the interception of tropical Atlantic marine air then this (combined with elevated [HCHO]) may account for the model under-prediction of $\left[\mathrm{HO}_{2}\right]$ at the beginning of the campaign. Furthermore, the sensitivity of modelled $\left[\mathrm{HO}_{2}\right]$ to aerosol uptake, coupled with the steep gradient in aerosol surface area from the ground to a height of $30 \mathrm{~m}$ (Sect. 2.3 ) suggests that $\left[\mathrm{HO}_{2}\right]$ could vary significantly with altitude within the BL.

In addition to heterogeneous loss to aerosols, surface deposition of $\mathrm{HO}_{2}$ to the surrounding ocean also contributes to the total $\mathrm{HO}_{2}$ sink within the model, albeit to a smaller extent, and may also promote variability in $\left[\mathrm{HO}_{2}\right]$ with altitude. Without a surface deposition term, modelled $\left[\mathrm{HO}_{2}\right]$ is $\sim 9 \%$ higher during the daytime and $\sim 16 \%$ at night. Prior to reaching the FAGE cell, the sampled air passed over $\sim 50 \mathrm{~m}$ of surf zone and rocks, in addition to the open ocean, and as this area is likely to have an increased surface roughness, leading to higher turbulence and hence contact with the ground, the surface deposition assuming loss to the ocean only is likely a lower limit for this region. The uncertainties in the magnitude of the surface deposition term could affect the overall magnitude of the modelled $\left[\mathrm{HO}_{2}\right]$, but are unlikely to account for the daily variablility in the measurements at the ground.

\section{Discussion and implications for MBL photochemistry}

Tropospheric $\mathrm{O}_{3}$ is an important greenhouse gas, providing a similar radiative forcing to methane, and $\sim 25 \%$ of that due to $\mathrm{CO}_{2}$ (Forster et al., 2007), and in the troposphere forms via the catalytic oxidation of $\mathrm{CO}$, methane and other VOCs in the presence of $\mathrm{NO}_{\mathrm{x}} \cdot \mathrm{O}_{3}$ production predominantly occurs in continental regions where $\mathrm{NO}_{\mathrm{x}}$ is elevated, whereas in the remote tropical marine boundary layer $\mathrm{O}_{3}$ is destroyed primarily through photolysis and subsequent reaction of the excited state oxygen atom with $\mathrm{H}_{2} \mathrm{O}$ vapour ( $\mathrm{Read}$ et al., 2008). During the RHaMBLe project at the CVAO, a daily $\mathrm{O}_{3}$ loss was observed of the order of $\sim 3.5 \mathrm{ppbv} \mathrm{d}^{-1}$. Taking the daytime average concentrations for the relevant measured species from the period 21 May-2 June 2007, the relative contributions to the observed chemical loss were calculated (concentration $\times$ rate coefficient), as shown in Table 3 and Fig. 10. The photolysis of $\mathrm{O}_{3}$ and subsequent reaction with $\mathrm{H}_{2} \mathrm{O}$ (Reactions R1 and R2) accounts for $\sim 40 \%$ of the daily $\mathrm{O}_{3}$ destruction. The reaction of $\mathrm{O}_{3}$ with $\mathrm{OH}(9 \%)$ (Reaction R3) and $\mathrm{HO}_{2}(12 \%)$ (Reaction R4) also contributes to its loss, owing to the relatively high concentrations of the radicals at the site, and reaction with $\mathrm{IO}(22.5 \%)$ and $\mathrm{BrO}$ (16.5\%) also destroy $\mathrm{O}_{3}$ (Reactions R5-R9). Table 3 highlights the relative importance of the reactions which contribute to the chemical destruction of $\mathrm{O}_{3}$. When combined, $\mathrm{BrO}$ and IO together destroy $\sim 1.5 \mathrm{ppbv} \mathrm{d}^{-1}$, whilst the loss due to the combined reaction with $\mathrm{OH}$ and $\mathrm{HO}_{2}$ is just under $1 \mathrm{ppbv} \mathrm{d}^{-1}$, in good agreement with estimates reported by Read et al. (2008) for the month of May. Read et al. (2008), however, used a box model to calculate $\mathrm{OH}$ and $\mathrm{HO}_{2}$ for the purposes of calculating the rate of $\mathrm{O}_{3}$ destruction, rather than using the measured values directly in the field, as presented here.

Aircraft measurements of $\mathrm{O}_{3}$ made above the CVAO during the RHaMBLe project (Read et al., 2008) demonstrated that the $\mathrm{O}_{3}$ destruction observed at ground level occurs throughout the entire MBL, which typically extends to $\sim 1 \mathrm{~km}$ altitude. The IO and BrO, observed by the LP-DOAS at the site, originate from the photolysis of organo-iodine compounds volatilised from the ocean and the acid-catalysed 
Table 3. The rates of the rate-limiting $\mathrm{O}_{3}$ destruction steps and their percentage contribution towards $\mathrm{O}_{3}$ destruction both in the surface layer and at the top of the MBL $(1 \mathrm{~km})$, see text for details.

\begin{tabular}{lrr}
\hline $\begin{array}{l}\mathrm{O}_{3} \text { destruction } \\
\text { rate determining } \\
\text { step }\end{array}$ & $\begin{array}{r}\text { Contribution to } \mathrm{O}_{3} \text { destruction } \\
\text { at the surface } \\
\left(\text { molecule } \mathrm{cm}^{-3} \mathrm{~s}^{-1}\right)\end{array}$ & $\begin{array}{r}\text { Contribution to } \mathrm{O}_{3} \\
\text { destruction at the top of the } \\
\mathrm{BL}\left(\text { molecule } \mathrm{cm}^{-3} \mathrm{~s}^{-1}\right)\end{array}$ \\
\hline $\mathrm{O}^{1} \mathrm{D}+\mathrm{H}_{2} \mathrm{O}$ & $9 \times 10^{5}(40 \%)$ & $9 \times 10^{5}(45 \%)$ \\
$\mathrm{OH}+\mathrm{O}_{3}$ & $2.1 \times 10^{5}(9 \%)$ & $2 \times 10^{5}(9 \%)$ \\
$\mathrm{HO}_{2}+\mathrm{O}_{3}$ & $2.6 \times 10^{5}(12 \%)$ & $3.8 \times 10^{5}(18 \%)$ \\
$\mathrm{IO}+\mathrm{IO}$ & $7.2 \times 10^{4}(3 \%)$ & $0 \%$ \\
$\mathrm{IO}+\mathrm{HO}_{2}$ & $3.6 \times 10^{5}(16 \%)$ & $0 \%$ \\
$\mathrm{IO}+\mathrm{NO}$ & $2.7 \times 10^{4}(1 \%)$ & $0 \%$ \\
$\mathrm{IO}+\mathrm{BrO}$ & $1.1 \times 10^{5}(5 \%)$ & $0 \%$ \\
$\mathrm{BrO}+\mathrm{BrO}$ & $1.4 \times 10^{4}(1 \%)$ & $2.7 \times 10^{4}(1 \%)$ \\
$\mathrm{BrO}+\mathrm{HO} \mathrm{H}_{2}$ & $2.1 \times 10^{5}(10 \%)$ & $4.5 \times 10^{5}(22 \%)$ \\
$\mathrm{BrO}+\mathrm{NO}$ & $6.7 \times 10^{4}(3 \%)$ & $9.4 \times 10^{4}(5 \%)$ \\
$\mathrm{Total}$ & $2.2 \times 10^{6}\left(3.91 \mathrm{ppbv} \mathrm{d}^{-1}\right)$ & $2.0 \times 10^{6}\left(3.59 \mathrm{ppbv} \mathrm{d}^{-1}\right)$ \\
\hline
\end{tabular}

activation of bromine from sea-salt aerosols, respectively (Read et al., 2008). There is some evidence to suggest that $[\mathrm{BrO}]$ may increase with altitude in the MBL (von Glasow et al., 2002) owing to an increase in the acidity of sea salt aerosols with altitude which enables acid catalysed bromine activation to occur more efficiently (von Glasow and Sander, 2001). It is uncertain, given the surface source of organo-iodine compounds and the short atmospheric lifetime of IO $(\sim 50 \mathrm{~s})$, whether this molecule also prevails throughout the MBL. The rate of heterogeneous loss of $\mathrm{HO}_{2}$ by uptake to aerosol surfaces and by surface deposition to the ocean (and/or rocky foreshore) will be at a maximum at ground level. The $\mathrm{HO}_{2}$ measurements were made just $3.5 \mathrm{~m}$ a.s.l. and, as discussed above, heterogeneous losses could reduce $\left[\mathrm{HO}_{2}\right]$ at the ground by $\sim 38 \%$ during the daytime. As a consequence of this, the $\mathrm{HO}_{2}$ concentration could increase with altitude in the boundary layer, and hence the rate of destruction of $\mathrm{O}_{3}$ by the $\mathrm{HO}_{2}+\mathrm{O}_{3}$ reaction will also increase with altitude. Further increases in $\left[\mathrm{HO}_{2}\right]$ with height may be expected as a consequence of a reduction in the [IO] with height.

A model scenario in which [IO], and heterogenous losses are set to zero and $[\mathrm{BrO}]$ is increased by a factor of 1.4 to simulate chemistry at the top of the MBL predicts that $\left[\mathrm{HO}_{2}\right]$ could be $52 \%$ higher than at the surface during the daytime (Table 2). Table 3 and Fig. 10, right panel, highlight the impact these changing parameters may have upon $\mathrm{O}_{3}$ destruction. A reduction in temperature $\left(\sim 5^{\circ} \mathrm{C}\right)$ is also considered as this has a small effect on the rate coefficients used. $\mathrm{An}_{3}$ loss rate of $\sim 3.91 \mathrm{ppbv} \mathrm{d}^{-1}$ is predicted at the surface and an $\mathrm{O}_{3}$ loss rate of $\sim 3.59 \mathrm{ppbv} \mathrm{d}^{-1}$ at the top of the MBL $(\sim 1 \mathrm{~km})$. Although these analyses only consider the chemical processes that lead to a loss in $\mathrm{O}_{3}$ and neglect physical processes, such as surface deposition and entrainment of $\mathrm{O}_{3}$, which can modify the overall $\mathrm{O}_{3}$ destruction, this work demonstrates the increase in $\mathrm{HO}_{2}$ and $\mathrm{BrO}$ concentrations is sufficient to compensate for the loss of IO at the higher altitudes. Aircraft measurements of $\mathrm{HO}_{2}$ made over the Pacific during the Transport and Chemical Evolution over the Pacific (TRACE-P) campaign (Cantrell et al., 2003) provides some evidence that $\mathrm{HO}_{2}$ concentrations increase over the first couple of kilometres. However, it is difficult to draw strong conclusions from the dataset due to the limited number of boundary layer observations that were made. Leser et al. (2003) have reported MAX-DOAS measurements of $\mathrm{BrO}$ taken onboard the R/V Polarstern north of the Canary Islands. Significant boundary layer $\mathrm{BrO}$ was observed, of the order of $1 \mathrm{pptv}$, although the vertical distribution within the boundary layer cannot be determined. Future, simultaneous observations of $\mathrm{O}_{3}, \mathrm{HO}_{2}$ and halogen oxides from $0-1 \mathrm{~km}$ from an aircraft platform, therefore, would be extremely beneficial.

Methane is removed from the atmosphere through oxidation by OH (Levy, 1971) with $\sim 25 \%$ of this removal occurring in the tropical MBL (Bloss et al., 2005a). In this work the important parameters which control the $\mathrm{OH}$ concentration in this region have been quantified, a number of which, until recently, have been overlooked, for example chemical processes involving halogen species. Although the vertical extent in the MBL of the impact of halogen oxides on the $\mathrm{HO}_{\mathrm{x}}$ and $\mathrm{O}_{3}$ budgets, particularly for IO, remains uncertain, these species constitute a significant source of $\mathrm{OH}$. Photolysis of $\mathrm{HOBr}$ and $\mathrm{HOI}$ lead to an increase in the $\mathrm{OH}$ concentration of $\sim 12 \%$, although this increase is offset slightly $(\sim 3 \%)$ by the perturbation of the $\mathrm{NO}_{\mathrm{x}}$ chemistry (lowering [NO]) by halogen oxides as discussed in Sect. 3.4.2 Overall, this work suggests that the methane lifetime is reduced by $\sim 9 \%$, due to the presence of halogen 
oxides leading to an increase in $[\mathrm{OH}]$. In the current atmosphere, one added methane molecule absorbs infra-red radiation $\sim 25$ times more efficiently than one additional $\mathrm{CO}_{2}$ molecule (Lelieveld et al., 1993) as $\mathrm{CO}_{2}$ is approximately 200 times more abundant in the atmosphere and, as a consequence, many of its absorption bands are saturated. Current estimates suggest that methane contributes a radiative forcing of $+0.48( \pm 0.05) \mathrm{Wm}^{-2}$ (Forster et al., 2007), which is $\sim 33 \%$ of that due to $\mathrm{CO}_{2}$. Radiative forcing from methane increases approximately as the square root of its concentration (Forster et al., 2007), and it is estimated that without halogen oxides, the lower $[\mathrm{OH}]$ would lead to an increase in the radiative forcing by methane by $\sim 3.5 \times 10^{-3} \mathrm{Wm}^{-2}$. A key remaining question is the range of altitudes over which halogen oxides, particularly IO, extend. To fully determine the global impact of the halogen oxides on the oxidising capacity of the tropical BL, manifested through their effect on $[\mathrm{OH}]$, the vertical profile of these species in this region is required.

\section{Summary}

Measurements of $\mathrm{OH}$ and $\mathrm{HO}_{2}$ radicals, together with a suite of supporting measurements, were made at the Cape Verde Atmospheric Observatory on the island of Sao Vicente during May and June 2007.

A model using the Master Chemical Mechanism, and constrained to the supporting measurements, was used to predict $\mathrm{OH}$ and $\mathrm{HO}_{2}$ concentrations and to probe the chemistry controlling the radicals at the observatory. The halogen oxides, despite their low concentrations, were found to act as a significant $\mathrm{HO}_{2}$ sink (19\%), with the subsequent photolysis of the hypohalous acids increasing the modelled [OH]. The model was able to capture daytime radical concentration reasonably well, with the model falling within the $1 \sigma$ measurement uncertainty of $20 \%$. During the night, the model significantly under-predicts $\left[\mathrm{HO}_{2}\right]$, we suggest that the thermolysis of 100 pptv of PAN, entrained from the cooler air aloft could account for the model-measurement discrepancy at this time.

Active halogen chemistry over the tropical oceans, where photochemical oxidation is most prevalent, can significantly impact the global oxidising capacity via its effect on $[\mathrm{OH}]$. From this work, the calculated methane lifetime could be as much as $9 \%$ shorter in this region if halogen chemistry is included in the calculation of [OH]. Currently, halogen chemistry is not routinely included in chemistry-transport models used to predict, for example, global distributions of tropopsheric methane and $\mathrm{O}_{3}$.

Further measurements of $\mathrm{OH}$ and $\mathrm{HO}_{2}$ coupled with concurrent measurements of halogen oxides, VOCs, HCHO, $\mathrm{HONO}, \mathrm{NO}_{\mathrm{x}}, \mathrm{NO}_{\mathrm{y}}$ and aerosol number and size distributions are needed to describe the chemistry of this region more fully and further test the hypotheses raised here. Vertical profiles of the concentrations of $\mathrm{IO}, \mathrm{BrO}, \mathrm{OH}, \mathrm{HO}_{2}$ and $\mathrm{O}_{3}$ are needed to discover if halogen chemistry has an impact on the budgets of $\mathrm{OH}, \mathrm{HO}_{2}$ and $\mathrm{O}_{3}$ throughout the boundary layer.

Acknowledgements. The authors would like to thank P. HalfordMaw and staff of the mechanical and electronic workshops within the School of Chemistry at the University of Leeds for their technical assistance in maintaining and developing the FAGE instrument. Thanks also to G. McFiggans for leading the RHaMBLe project and L. Mendes and B. Faria for campaign and logistical organisation and to C. Seal for assistance with pack-up. The NERC SOLAS project is acknowledged for the funding of the CVAO and NCAS for the long-term support of the FGAM FAGE instrument. This work was supported by NERC under grant number NE/D006589/1.

Edited by: R. von Glasow

\section{References}

Abbatt, J. P. D. and Waschewsky, G. C. G.: Heterogeneous interactions of $\mathrm{HOBr}, \mathrm{HNO}_{3}, \mathrm{O}_{3}$, and $\mathrm{NO}_{2}$ with deliquescent $\mathrm{NaCl}$ aerosols at room temperature, J. Phys. Chem. A, 102, 37193725, 1998.

Alicke, B., Hebestreit, K., Stutz, J., and Platt, U.: Iodine oxide in the marine boundary layer, Nature, 397, 572-573, 1999.

Allan, B. J., McFiggans, G., Plane, J. M. C., and Coe, H.: Observations of iodine monoxide in the remote marine boundary layer, J. Geophys. Res.- Atmos., 105, 14363-14369, 2000.

Allan, J. D., Topping, D. O., Good, N., Irwin, M., Flynn, M., Williams, P. I., Coe, H., Baker, A. R., Martino, M., Niedermeier, N., Wiedensohler, A., Lehmann, S., Müller, K., Herrmann, H., and McFiggans, G.: Composition and properties of atmospheric particles in the eastern Atlantic and impacts on gas phase uptake rates, Atmos. Chem. Phys., 9, 9299-9314, 2009,

http://www.atmos-chem-phys.net/9/9299/2009/.

Ayers, G. P., Penkett, S. A., Gillett, R. W., Bandy, B., Galbally, I. E., Meyer, C. P., Elsworth, C. M., Bentley, S. T., and Forgan, B. W.: The annual cycle of peroxides and ozone in marine air at Cape Grim, Tasmania, J. Atmos. Chem., 23, 221-252, 1996.

Bielski, B. H. J.: Re-Evaluation of Spectral and Kinetic-Properties of $\mathrm{HO}_{2}$ and $\mathrm{O}_{2}^{-}$Free-Radicals, Photochem. Photobiol., 28, 645649, 1978.

Bloss, W. J., Evans, M. J., Lee, J. D., Sommariva, R., Heard, D. E., and Pilling, M. J.: The oxidative capacity of the troposphere: Coupling of field measurements of $\mathrm{OH}$ and a global chemistry transport model, Faraday Discuss., 130, 425-436, 2005 a.

Bloss, W. J., Lee, J. D., Johnson, G. P., Sommariva, R., Heard, D. E., Saiz-Lopez, A., Plane, J. M. C., McFiggans, G., Coe, H., Flynn, M., Williams, P., Rickard, A. R., and Fleming, Z. L.: Impact of halogen monoxide chemistry upon boundary layer $\mathrm{OH}$ and $\mathrm{HO}_{2}$ concentrations at a coastal site, Geophys. Res. Lett., 32, L06814, doi:10.1029/2004GL022084, 2005b.

Bloss, W. J., Lee, J. D., Heard, D. E., Salmon, R. A., Bauguitte, S. J.-B., Roscoe, H. K., and Jones, A. E.: Observations of $\mathrm{OH}$ and $\mathrm{HO}_{2}$ radicals in coastal Antarctica, Atmos. Chem. Phys., 7, 4171-4185, 2007, http://www.atmos-chem-phys.net/7/4171/2007/. 
Brasseur, G. P., Hauglustaine, D. A., Walters, S., Rasch, P. J., Muller, J. F., Granier, C., and Tie, X. X.: MOZART, a global chemical transport model for ozone and related chemical tracers, 1. Model description, J. Geophys. Res.-Atmos., 103, 2826528289, 1998.

Brauers, T., Hausmann, M., Bister, A., Kraus, A., and Dorn, H. P.: $\mathrm{OH}$ radicals in the boundary layer of the Atlantic Ocean, 1. Measurements by long-path laser absorption spectroscopy, J. Geophys. Res.-Atmos., 106, 7399-7414, 2001.

Bridier, I., Caralp, F., Loirat, H., Lesclaux, R., Veyret, B., Becker, K. H., Reimer, A., and Zabel, F.: Kinetic and theoretical studies of the reactions $\mathrm{CH}_{3} \mathrm{C}(\mathrm{O}) \mathrm{O}_{2}+\mathrm{NO}_{2}+\mathrm{M} \longleftrightarrow \mathrm{CH}_{3} \mathrm{C}(\mathrm{O}) \mathrm{O}_{2} \mathrm{NO}_{2}+\mathrm{M}$ between 248 and $393 \mathrm{~K}$ and between 30-760 torr, J. Phys. Chem., 95, 3594-3600, 1991.

Cantrell, C. A., Edwards, G. D., Stephens, S., Mauldin, R. L., Zondlo, M. A., Kosciuch, E., Eisele, F. L., Shetter, R. E., Lefer, B. L., Hall, S., Flocke, F., Weinheimer, A., Fried, A., Apel, E., Kondo, Y., Blake, D. R., Blake, N. J., Simpson, I. J., Bandy, A. R., Thornton, D. C., Heikes, B. G., Singh, H. B., Brune, W. H., Harder, H., Martinez, M., Jacob, D. J., Avery, M. A., Barrick, J. D., Sachse, G. W., Olson, J. R., Crawford, J. H., and Clarke, A. D.: Peroxy radical behavior during the Transport and Chemical Evolution over the Pacific (TRACE-P) campaign as measured aboard the NASA P-3B aircraft, J. Geophys. Res.-Atmos., 108(D20), 8797, doi:10.1029/2003JD003674, 2003.

Carpenter, L. J., Monks, P. S., Bandy, B. J., Penkett, S. A., Galbally, I. E., and Meyer, C. P.: A study of peroxy radicals and ozone photochemistry at coastal sites in the northern and southern hemispheres, J. Geophys. Res.-Atmos., 102, 25417-25427, 1997.

Carpenter, L. J., Sturges, W. T., Penkett, S. A., Liss, P. S., Alicke, B., Hebestreit, K., and Platt, U.: Short-lived alkyl iodides and bromides at Mace Head, Ireland: Links to biogenic sources and halogen oxide production, J. Geophys. Res.-Atmos., 104, 16791689, 1999.

Carpenter, L. J., Lewis, A. C., Hopkins, J. R., Read, K. A., Longley, I. D., and Gallagher, M. W.: Uptake of methanol to the North Atlantic Ocean surface, Global Biogeochem. Cy., 18, 4, doi:10.1029/2004GB002294, 2004.

Chameides, W. L. and Davis, D.: Iodine - its possible role in tropospheric photochemistry, J. Geophys. Res.-Atmos., 85, 73837398, 1980.

Chang, W., Heikes, B., and Lee, M.: Ozone deposition to the sea surface: chemical enhancement and wind speed dependence, Atmos. Environ., 38, 1053-1059, 2004.

Chen, G., Davis, D., Crawford, J., Heikes, B., O'Sullivan, D., Lee, M., Eisele, F., Mauldin, L., Tanner, D., Collins, J., Barrick, J., Anderson, B., Blake, D., Bradshaw, J., Sandholm, S., Carroll, M., Albercook, G., and Clarke, A.: An assessment of $\mathrm{HO}_{\mathrm{x}}$ chemistry in the Tropical Pacific Boundary Layer: Comparison of model simulations with observations recorded during PEM Tropics A, J. Atmos. Chem., 38, 317-344, 2001.

Commane, R.: Understanding radical chemistry throughout the troposphere using laser-induced fluorescence spectroscopy, University of Leeds, 2009.

Curtis, A. R. and Sweetenham, W. P.: FACSIMILE/CHEKMAT users manual, in: Her majesty's stn. off, edited by: AERER12805, Norwich, England, 1987.
Dickerson, R. R., Rhoads, K. P., Carsey, T. P., Oltmans, S. J., Burrows, P. J., and Crutzen, P. J.: Ozone in the remote marine boundary layer: A possible role for halogens, J. Geophys. Res.-Atmos., 104, 21385-21395, 1999.

Fairall, C. W., Hare, J. E., Edson, J. B., and McGillis, W.: Parameterization and micrometeorological measurement of air-sea gas transfer, Bound.-Lay. Meteorol., 96, 63-105, 2000.

Fairall, C. W., Helmig, D., Ganzeveld, L., and Hare, J.: Waterside turbulence enhancement of ozone deposition to the ocean, Atmos. Chem. Phys., 7, 443-451, 2007,

http://www.atmos-chem-phys.net/7/443/2007/.

Fleming, Z. L., Monks, P. S., Rickard, A. R., Heard, D. E., Bloss, W. J., Seakins, P. W., Still, T. J., Sommariva, R., Pilling, M. J., Morgan, R., Green, T. J., Brough, N., Mills, G. P., Penkett, S. A., Lewis, A. C., Lee, J. D., Saiz-Lopez, A., and Plane, J. M. C.: Peroxy radical chemistry and the control of ozone photochemistry at Mace Head, Ireland during the summer of 2002, Atmos. Chem. Phys., 6, 2193-2214, 2006,

http://www.atmos-chem-phys.net/6/2193/2006/.

Furneaux, K. L., Whalley, L. K., Heard, D. E., Atkinson, H. M., Bloss, W. J., Flynn, M. J., Gallagher, M. W., Ingham, T., Kramer, L., Lee, J. D., Leigh, R., McFiggans, G. B., Mahajan, A. S., Monks, P. S., Oetjen, H., Plane, J. M. C., and Whitehead, J. D.: Measurements of iodine monoxide at a semi polluted coastal location, Atmos. Chem. Phys. Discuss., 9, 25737-25797, 2009, http://www.atmos-chem-phys-discuss.net/9/25737/2009/.

Galbally, I. E., Bentley, S. T., and Meyer, C. P.: Mid-latitude marine boundary layer ozone destruction at visible sunrise observed at Cape Grim, Tasmania, 41 degrees S, Geophys. Res. Lett., 27, 3841, doi:10.1029/1999GL010943, 2000.

Gallagher, M. S., Carsey, T. P., and Farmer, M. L.: Peroxyacetyl nitrate in the north Atlantic marine boundary layer, Global Biogeochem. Cy., 4, 297-308, 1990.

Ganzeveld, L. and Lelieveld, J.: Dry Deposition Parameterization in a Chemistry General-Circulation Model and Its Influence on the Distribution of Reactive Trace Gases, J. Geophys. Res.-Atmos., 100, 20999-21012, 1995.

Haggerstone, A.-L., Carpenter, L. J., Carslaw, N., and McFiggans, G.: Improved model predictions of $\mathrm{HO}_{2}$ with gas to particle mass transfer rates calculated using aerosol number size distribution, J. Geophys. Res.-Atmos., 110(D4), D04304, doi:10.1029/2004JD005282, 2005.

Heard, D. E. and Pilling, M. J.: Measurement of $\mathrm{OH}$ and $\mathrm{HO}_{2}$ in the Tropopshere, Chem. Rev., 103, 5163-5198, 2003.

Hoell, J. M., Davis, D., Liu, S., Newell, R. E., Shipman, M., Akimoto, H., McNeal, R. J., Bendura, R. J., and Drewry, J. W.: Pacific Exploratory Mission-West A (PEM-West A) SeptemberOctober 1991, J. Geophys. Res.-Atmos., 101, 1641-1653, 1996.

Hoell, J. M., Davis, D., Liu, S., Newell, R. E., Akimoto, H., McNeal, R. J., and Bendura, R. J.: The Pacific Exploratory MissionWest Phase B: February-March 1994, J. Geophys. Res.-Atmos., 102, 28223-28239, 1997.

Hoell, J. M., Davis, D., Jacob, D. J., Rodgers, M. O., Newell, R. E., Fuelberg, H. E., McNeal, R. J., Raper, J. L., and Bendura, R. J.: Pacific Exploratory Mission in the tropical Pacific: PEMTropics A, August-September 1996, J. Geophys. Res.-Atmos., 104, 5567-5583, 1999. 
Hough, A. M.: The calculation of photolysis rates for use in global tropospheric modelling studies, AERE rep., Her Majesty's Stn. Off., Norwich, 1988.

IUPAC: http://www.iupac-kinetic.ch.cam.ac.uk/, last access: 8 July 2009, 2006.

Jacobi, H.-W., Weller, R., Bluszcz, T., and Schrems, O.: Latitudinal distribution of peroxyacetyl nitrate (PAN) over the Atlantic ocean, J. Geophys. Res.-Atmos., 104, 26901-26912, 1999.

Junkermann, W. and Stockwell, W. R.: On the budget of photooxidants in the marine boundary layer of the tropical South Atlantic, J. Geophys. Res.-Atmos., 104, 8039-8046, 1999.

Kanaya, Y., Cao, R., Kato, S., Miyakawa, Y., Kajii, Y., Tanimoto, H., Yokouchi, Y., Mochida, M., Kawamura, K., and Akimoto, H.: Chemistry of $\mathrm{OH}$ and $\mathrm{HO}_{2}$ radicals observed at Rishiri Island, Japan, in September 2003: Missing daytime sink of $\mathrm{HO}_{2}$ and positive nighttime correlations with monoterpenes, J. Geophys. Res.-Atmos., 112, D11308, doi:10.1029/2006JD007987, 2007.

Keene, W. C., Long, M. S., Pszenny, A. A. P., Sander, R., Maben, J. R., Wall, A. J., O’Halloran, T. L., Kerkweg, A., Fischer, E. V., and Schrems, O.: Latitudinal variation in the multiphase chemical processing of inorganic halogens and related species over the eastern North and South Atlantic Oceans, Atmos. Chem. Phys., 9, 7361-7385, 2009,

http://www.atmos-chem-phys.net/9/7361/2009/.

Lee, J. D., McFiggans, G., Allan, J. D., Baker, A. R., Ball, S. M., Benton, A. K., Carpenter, L. J., Commane, R., Finley, B. D., Evans, M., Fuentes, E., Furneaux, K., Goddard, A., Good, N., Hamilton, J. F., Heard, D. E., Herrmann, H., Hollingsworth, A., Hopkins, J. R., Ingham, T., Irwin, M., Jones, C. E., Jones, R. L., Keene, W. C., Lawler, M. J., Lehmann, S., Lewis, A. C., Long, M. S., Mahajan, A., Methven, J., Moller, S. J., Müller, K., Müller, T., Niedermeier, N., O’Doherty, S., Oetjen, H., Plane, J. M. C., Pszenny, A. A. P., Read, K. A., Saiz-Lopez, A., Saltzman, E. S., Sander, R., von Glasow, R., Whalley, L., Wiedensohler, A., and Young, D.: Reactive Halogens in the Marine Boundary Layer (RHaMBLe): the tropical North Atlantic experiments, Atmos. Chem. Phys., 10, 1031-1055, 2010,

http://www.atmos-chem-phys.net/10/1031/2010/.

Lee, J. D., Moller, S. J., Read, K. A., Lewis, A. C., Mendes, L., and Carpenter, L. J.: Year round measurements of nitrogen oxides and ozone in the tropical North Atlantic marine boundary layer, J. Geophys. Res., 114, D21, doi:10.1029/2009JD011878, 2009.

Lelieveld, J., Crutzen, P. J., and Bruhl, C.: Climate effects of atmospheric methane, Chemosphere, 26, 739-768, 1993.

Leser, H., Honninger, G., and Platt, U.: MAX-DOAS measurements of $\mathrm{BrO}$ and $\mathrm{NO}_{2}$ in the marine boundary layer, Geophys. Res. Lett., 30, 1537, doi:10.1029/2002GL015811, 2003.

Levy, H.: Normal atmosphere: Large radical and formaldehyde concentrations predicted, Science, 173, 141-143, 1971.

Mahajan, A. S., Plane, J. M. C., Oetjen, H., Whalley, L., Furneaux, K., Ingham, T., Heard, D., and Saiz-Lopez, A.: Long term DOAS observations of formaldehyde over the tropical Atlantic Ocean in preparation, in preparation, 2010.

Mauldin III, R. L., Tanner, D., and Eisele, F.: Measurements of $\mathrm{OH}$ during PEM-Tropics A, J. Geophys. Res.-Atmos., 104, 58175827, 1999.
Mauldin III, R. L., Eisele, F., Cantrall, C., Kosciuch, E., Ridley, B. A., Lefer, B., Tanner, D., Nowak, J. B., Chen, G., Wang, L., and Davis, D.: Measurements of $\mathrm{OH}$ aboard the NASA P-3 during PEM-Tropics B, J. Geophys. Res.-Atmos., 106, 32657-32666, 2001.

MCM: Master Chemical Mechanism, Version 3.1, http://mcm. leeds.ac.uk/MCM/home, last access: 08 July 2009.

Monks, P. S., Carpenter, L. J., Penkett, S. A., Ayers, G. P., Gillett, R. W., Galbally, I. E., and Meyer, C. P.: Fundamental ozone photochemistry in the remote marine boundary layer: The SOAPEX experiment, measurement and theory, Atmos. Environ., 32, 3647-3664, 1998.

Moore, R., Oram, D., and Penkett, S. A.: Production of isoprene by marine phytoplankton cultures, Geophys. Res. Lett., 21, 25072510, 1994.

Mossinger, J. C. and Cox, R. A.: Heterogeneous reaction of HOI with sodium halide salts, J. Phys. Chem. A, 105, 5165-5177, 2001.

Müller, K. P. and Rudolph, J.: Measurements of peroxyacetylnitrate in the marine boundary layer over the Atlantic, J. Atmos. Chem., 15, 3-4, 1992.

Pechtl, S., Schmitz, G., and von Glasow, R.: Modelling iodide iodate speciation in atmospheric aerosol: Contributions of inorganic and organic iodine chemistry, Atmos. Chem. Phys., 7, 1381-1393, 2007, http://www.atmos-chem-phys.net/7/1381/2007/.

Penkett, S. A., Monks, P. S., Carpenter, L. J., Clemitshaw, K. C., Ayers, G. P., Gillett, R. W., Galbally, I. E., and Meyer, C. P.: Relationship between ozone photolysis rates and peroxy radical concentrations in clean marine air over the Southern Ocean, J. Geophys. Res.-Atmos., 102, 12805-12817, 1997.

Plane, J. M. C. and Saiz-Lopez, A.: UV-Visible Differential Optical Absorption Spectroscopy (DOAS), in: Analytical Techniques for Atmospheric Measurements, edited by: Heard, D. E., Blackwell Publishing, 147-180 pp., 2006.

Plane, J. M. C.: Personal Communication, 2009.

Poppe, D.: Time constant analysis of tropospheric gas-phase chemistry, Phys. Chem. Chem. Phys., 1, 5417-5422, 1999.

Raper, J. L., Kleb, M. M., Jacob, D. J., Davis, D., Newell, R. E., Fuelberg, H. E., Bendura, R. J., Hoell, J. M., and McNeal, R. J.: Pacific Exploratory Mission in the Tropical Pacific: PEMTropics B, March-April 1999, J. Geophys. Res.-Atmos., 106, 32401-32425, 2001.

Ravishankara, A. R.: Heterogeneous and multiphase chemistry in the troposphere, Science, 276, 1058-1065, 1997.

Read, K. A., Mahajan, A. S., Carpenter, L. J., Evans, M. J., Faria, B. V. E., Heard, D. E., Hopkins, J. R., Lee, J. D., Moller, S. J., Lewis, A. C., Mendes, L., McQuaid, J. B., Oetjen, H., SaizLopez, A., Pilling, M. J., and Plane, J. M. C.: Extensive halogenmediated ozone destruction over the tropical Atlantic Ocean, Nature, 453, 1232-1235, 2008.

Read, K. A., Lee, J. D., Lewis, A. C., Moller, S. J., Neves, L. M., and Carpenter, L. J.: Intra-annual cycles of NMVOC in the tropical marine boundary layer and their use for interpreting seasonal variability in CO, J. Geophys. Res., 114, D21, doi:10.1029/2009JD011879, 2009. 
Read, K. A., Lewis, A. C., Mendes, L., Whalley, L. K., and Carpenter, L. J.: VOCs in the tropical remote marine boundary layer: Trends, ocean influence and atmospheric impacts, in preparation, 2010.

Saiz-Lopez, A. and Plane, J. M. C.: Novel iodine chemistry in the marine boundary layer, Geophys. Res. Lett., 31, 4, doi:10.1029/2003GL09215, 2004a.

Saiz-Lopez, A., Plane, J. M. C., and Shillito, J.: Bromine oxide in the mid-latitude marine boundary layer, Geophys. Res. Lett., 31(3), L03111, doi:10.1029/2003GL018956, 2004 b.

Salisbury, G., Rickard, A. R., Monks, P. S., Allan, B. J., Bauguitte, S., Penkett, S. A., Carslaw, N., Lewis, A. C., Creasey, D. J., Heard, D. E., Jacobs, P. J., and Lee, J. D.: Production of peroxy radicals at night via reactions of ozone and the nitrate radical in the marine boundary layer, J. Geophys. Res.-Atmos., 106, 12669-12687, 2001.

Sander, R.: Modeling atmospheric chemistry: interactions between gas-phase species and liquid cloud/aerosols particles, Surv. Geophys., 20, 1-31, 1999.

Saunders, S. M., Jenkin, M. E., Derwent, R. G., and Pilling, M. J.: Protocol for the development of the Master Chemical Mechanism, MCM v3 (Part A): tropospheric degradation of nonaromatic volatile organic compounds, Atmos. Chem. Phys., 3, 161-180, 2003, http://www.atmos-chem-phys.net/3/161/2003/.

Schwartz, S. E.: Gas-Phase and Aqueous-Phase Chemistry of $\mathrm{HO}_{2}$ in Liquid Water Clouds, J. Geophys. Res.-Atmos., 89, 15891598, 1984.

Shaw, S. L., Chisholm, S. W., and Prinn, R. G.: Isoprene production by Prochlorococcus, a marine cyanobacterium and other phytoplankton, Mar. Chem., 80, 227-245, 2003.

Singh, H. B., Chen, Y., Staudt, A., Jacob, D., Blake, D., Heikes, B., and Snow, J.: Evidence from the Pacific troposphere for large global sources of oxygenated organic commpounds, Nature, 410, 1078-1081, 2001.

Singh, H. B., Tabazadeh, A., Evans, M. J., Field, B. D., Jacob, D. J., Sachse, G., Crawford, J. H., Shetter, R., and Brune, W. H.: Oxygenated volatile organic chemicals in the oceans: Inferences and implications based on atmospheric observations and air-sea exchange models, Geophys. Res. Lett., 30(16), 1862, doi:10.1029/2003GL017933, 2003.

Smith, S. C., Lee, J. D., Bloss, W. J., Johnson, G. P., Ingham, T., and Heard, D. E.: Concentrations of $\mathrm{OH}$ and $\mathrm{HO}_{2}$ radicals during NAMBLEX: measurements and steady state analysis, Atmos. Chem. Phys., 6, 1435-1453, 2006, http://www.atmos-chem-phys.net/6/1435/2006/.

Smith, S. C. Atmospheric measurements of $\mathrm{OH}$ and $\mathrm{HO}_{2}$ using the FAGE technique: Instrument development and data analysis, University of Leeds, 2007.

Sommariva, R., Haggerstone, A.-L., Carpenter, L. J., Carslaw, N., Creasey, D. J., Heard, D. E., Lee, J. D., Lewis, A. C., Pilling, M. J., and Zádor, J.: $\mathrm{OH}$ and $\mathrm{HO}_{2}$ chemistry in clean marine air during SOAPEX-2, Atmos. Chem. Phys., 4, 839-856, 2004, http://www.atmos-chem-phys.net/4/839/2004/.
Sommariva, R., Bloss, W. J., Brough, N., Carslaw, N., Flynn, M., Haggerstone, A.-L., Heard, D. E., Hopkins, J. R., Lee, J. D., Lewis, A. C., McFiggans, G., Monks, P. S., Penkett, S. A., Pilling, M. J., Plane, J. M. C., Read, K. A., Saiz-Lopez, A., Rickard, A. R., and Williams, P. I.: $\mathrm{OH}$ and $\mathrm{HO}_{2}$ chemistry during NAMBLEX: roles of oxygenates, halogen oxides and heterogeneous uptake, Atmos. Chem. Phys., 6, 1135-1153, 2006, http://www.atmos-chem-phys.net/6/1135/2006/.

Stull, R. B.: Introduction to Boundary Layer Meteorology, Publishers, K. A., Dordrecht, 1988.

Taketani, F., Kanaya, Y., and Akimoto, H.: Kinetcis of heterogeneous reactions of $\mathrm{HO}_{2}$ radical at ambient concentration levels with $\left(\mathrm{NH}_{4}\right)_{2} \mathrm{SO}_{4}$ and $\mathrm{NaCl}$ aerosol particles, J. Phys. Chem. A, 112, 2370-2377, 2008.

Taketani, F., Kanaya, Y., and Akimoto, H.: Heterogeneous loss of $\mathrm{HO}_{2}$ by $\mathrm{KCl}$, synthetic sea salt, and natural seawater aerosol particles, Atmos. Environ., 43, 1660-1665, 2009.

Thornton, J. A., Jaegle, L., and McNeill, V. F.: Assessing known pathways for $\mathrm{HO}_{2}$ loss in aqueous atmospheric aerosols: Regional and global impacts on tropospheric oxidants, J. Geophys. Res.-Atmos., 113, D05303, doi:10.1029/2007JD009236, 2008.

Vogt, R., Crutzen, P. J., and Sander, R.: A mechanism for halogen release from sea-salt aerosol in the remote marine boundary layer, Nature, 383, 327-330, 1996.

Vogt, R., Sander, R., von Glasow, R., and Crutzen, P. J.: Iodine chemistry and its role in halogen activation and ozone loss in the marine boundary layer: A model study, J. Atmos. Chem., 32, 375, doi:10.1023/A:1006179901037, 1999.

von Glasow, R. and Sander, R.: Variation of sea salt aerosol pH with relative humidity, Geophys. Res. Lett., 28, 247-250, 2001.

von Glasow, R., Sander, R., Bott, A., and Crutzen, P. J.: Modelling halogen chemistry in the marine boundary layer - 1. Cloud-free MBL, J. Geophys. Res.-Atmos., 107, 4341, doi:10.1029/2001JD000942, 2002.

von Glasow, R., von Kuhlmann, R., Lawrence, M. G., Platt, U., and Crutzen, P. J.: Impact of reactive bromine chemistry in the troposphere, Atmos. Chem. Phys., 4, 2481-2497, 2004,

http://www.atmos-chem-phys.net/4/2481/2004/.

von Glasow, R.: Personal Communication, 2009.

Wachsmuth, M., Gäggeler, H. W., von Glasow, R., and Ammann, M.: Accommodation coefficient of $\mathrm{HOBr}$ on deliquescent sodium bromide aerosol particles, Atmos. Chem. Phys., 2, 121131, 2002, http://www.atmos-chem-phys.net/2/121/2002/.

Weller, R., Schrems, O., Boddenberg, A., Gäb, S., and Gautrois, M.: Meridional distribution of hydroperoxides and formaldehyde in the marine boundary layer of the Atlantic $\left(48^{\circ} \mathrm{N}-35^{\circ} \mathrm{S}\right)$ measured during the Albatross campaign, J. Geophys. Res.-Atmos. ,105, 14401-14412, 2000.

Whalley, L. K., Furneaux, K. L., Gravestock, T., Atkinson, H. M., Bale, C. S. E., Ingham, T., Bloss, W. J., and Heard, D. E.: Detection of iodine monoxide radicals in the marine boundary layer using laser induced fluorescence spectroscopy, J. Atmos. Chem., 58, 19-39, 2007. 